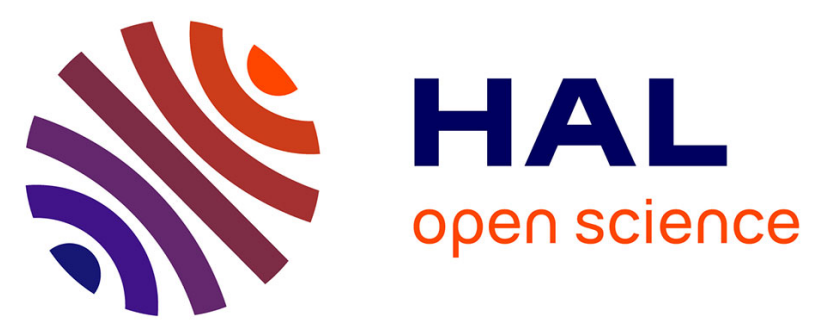

\title{
Plio-Pleistocene sedimentation in West Turkana (Turkana Depression, Kenya, East African Rift System): Paleolake fluctuations, paleolandscapes and controlling factors
}

Alexis Nutz, M. Schuster, Doris Barboni, Ghislain Gassier, Bert Van

Bocxlaer, Cécile Robin, T. Ragon, J.-F. Ghienne, J.-L. Rubino

\section{To cite this version:}

Alexis Nutz, M. Schuster, Doris Barboni, Ghislain Gassier, Bert Van Bocxlaer, et al.. Plio-Pleistocene sedimentation in West Turkana (Turkana Depression, Kenya, East African Rift System): Paleolake fluctuations, paleolandscapes and controlling factors. Earth-Science Reviews, 2020, 211, pp.1-32. 10.1016/j.earscirev.2020.103415 . insu-02981457

\section{HAL Id: insu-02981457}

https://hal-insu.archives-ouvertes.fr/insu-02981457

Submitted on 28 Oct 2020

HAL is a multi-disciplinary open access archive for the deposit and dissemination of scientific research documents, whether they are published or not. The documents may come from teaching and research institutions in France or abroad, or from public or private research centers.
L'archive ouverte pluridisciplinaire HAL, est destinée au dépôt et à la diffusion de documents scientifiques de niveau recherche, publiés ou non, émanant des établissements d'enseignement et de recherche français ou étrangers, des laboratoires publics ou privés. 


\section{Journal Pre-proof}

Plio-Pleistocene sedimentation in West Turkana (Turkana Depression, Kenya, East African Rift System): Paleolake fluctuations, paleolandscapes and controlling factors

A. Nutz, M. Schuster, D. Barboni, G. Gassier, B. Van Bocxlaer, C. Robin, T. Ragon, J.-F. Ghienne, J.-L. Rubino



PII: $\quad$ S0012-8252(20)30461-X

DOI: $\quad$ https://doi.org/10.1016/j.earscirev.2020.103415

Reference: $\quad$ EARTH 103415

To appear in: $\quad$ Earth-Science Reviews

Received date: $\quad 17$ July 2020

Revised date: $\quad 10$ October 2020

Accepted date: $\quad 19$ October 2020

Please cite this article as: A. Nutz, M. Schuster, D. Barboni, et al., Plio-Pleistocene sedimentation in West Turkana (Turkana Depression, Kenya, East African Rift System): Paleolake fluctuations, paleolandscapes and controlling factors, Earth-Science Reviews (2020), https://doi.org/10.1016/j.earscirev.2020.103415

This is a PDF file of an article that has undergone enhancements after acceptance, such as the addition of a cover page and metadata, and formatting for readability, but it is not yet the definitive version of record. This version will undergo additional copyediting, typesetting and review before it is published in its final form, but we are providing this version to give early visibility of the article. Please note that, during the production process, errors may be discovered which could affect the content, and all legal disclaimers that apply to the journal pertain.

(C) 2020 Published by Elsevier. 


\title{
Plio-Pleistocene sedimentation in West Turkana (Turkana Depression,
}

\section{Kenya, East African Rift System): paleolake fluctuations, paleolandscapes}

\section{and controlling factors}

\author{
A. Nutz ${ }^{1, *}$ nutz@cerege.fr, M. Schuster ${ }^{2}$, D. Barboni ${ }^{1}$, G. Gassier ${ }^{1}$, B. Van Bocxlaer ${ }^{3}$, C. \\ Robin $^{4}$, T. Ragon ${ }^{5}$, J-F. Ghienne ${ }^{2}$, J-L. Rubino ${ }^{6}$ \\ ${ }^{1}$ CEREGE, Aix-Marseille Université, CNRS, IRD, Collège de France, INRA, Aix en Pro- \\ vence, France.
}

${ }^{2}$ Institut de Physique du Globe de Strasbourg (IPGS), U. 1R 7516 CNRS-Université de Strasbourg, EOST, 1 rue Blessig, 67084 Strasbourg, Frar zt.

${ }^{3}$ Evo-Eco-Paleo, UMR 8198 CNRS-Université de ille Bâtiment SN2, Cité Scientifique, 59000 Lille, France

${ }^{4}$ Laboratoire Géosciences Rennes, Univer ‥' a Rennes 1, UMR 6118 CNRS/INSU, Campus de Beaulieu, 35042 Rennes, France

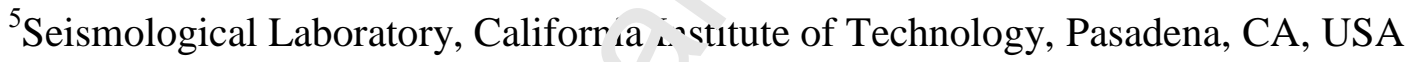

${ }^{6}$ Total S.A., CSTJF, Avenue Larr: ıau, j4018 Pau Cedex, France

*Corresponding author.

\section{ABSTRACT}

Pliocene and Pleistocene sediments from West Turkana (Kenya, East African Rift System) form emblematic syn-rift successions for understanding the evolution of extensional basin and continental rifting. They also constitute world-renowned fossil-bearing strata from which $>500$ hominin fossils were discovered over the past decades, with $>100$ inventoried archaeological sites. However, associated sedimentary dynamics and architectures as well as paleoenvironments are only partially reconstructed and the relative contribution of climate 
and tectonism to paleoenvironmental change over time remains unclear. Here, through the interpretation of sedimentary facies, the delineation of sequences and the analysis of $\delta^{13} \mathrm{C}$ in soil carbonates, we provide the first exhaustive reconstruction from $\sim 4$ to $\sim 0.75 \mathrm{Ma}$ of (i) fluctuations of the paleolake that occupied the Turkana Depression, (ii) the successive sedimentary dynamics and related paleolandscapes that characterized the West Turkana area and (iii) respective roles of climate and tectonism in the sedimentation. We show evidence for seven major transgression-regression (T-R) cycles between $\sim 4$ and $\sim 0.75$ Ma superimposed locally by lower amplitude T-R cycles., Comparing the sedim ^nt॰ 'ogical interpretations and the $\delta^{13} \mathrm{C}$ values in soil carbonates (literature data), we rev sal . hat fluctuations of rainfall over the Ethiopian Dome, which hosts the drainage basin $\int^{c} t_{h}$ Omo River - the main tributary of Lake Turkana - controlled high-amplitude 1/ke 'evel fluctuations during the PlioPleistocene period. We also demonstrate that eg_..tion and tree cover evolved differently in the Omo Valley and West Turkana. Furi:- more we outline that two different sedimentary systems reflecting two distinct modes $\omega^{c}$ sedimentation alternated through times in the West

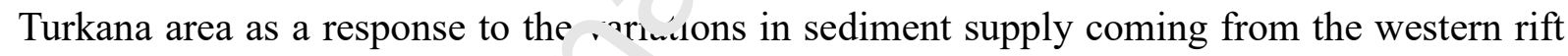
shoulder (i.e. Lapurr Range, that alternatively generated wave- or river-dominated sedimentary systems. In $\sim n_{\text {L.sion, }}$ we reveal that climate regulated water input, paleolake water-level fluctuations . nd vegetation. Tectonism determined sediment supply to the basin controlled in West Turkana by pulses of increased activity of the main border fault (i.e., the Murua Rith Lapurr Fault).

KEYWORDS: Nachukui Fm, Omo Group, rift basin, Pliocene

\section{INTRODUCTION}

The Turkana Depression has been investigated for several decades, the deposition and preservation of thick syn-rift strata in this area providing a thorough record of the evolution of 
the East African Cenozoic rifting from $\sim 35$ million years ago to the present. In the early1980's, ambitious seismic imagery campaigns (Amoco Kenya Petroleum company and project PROBE) boosted geological investigations, while the first detailed stratigraphical and sedimentological analyses were performed (de Heinzelin, 1983; Brown and Feibel, 1986; Harris et al., 1988). Seismic imagery revealed that the Turkana Depression is composed of several individual grabens and half-grabens filled by $>3 \mathrm{~km}$ of Neogene sediments (Dunkelman et al., 1988; 1989; Morley et al., 1992). After the 1990's, additional seismic reflection, gravity and magnetic data, deep and shallow wells and geological analysis of outcrops led to the elaboration of a complex structural framework that shed light on fundamental geotectonic processes associated with conlivental rifting (Morley et al., 1999; Vétel and Le Gall, 2006; Brune et al., 2017; Ragon eı rl., 2019; Morley, 2020). In parallel, sedimentary processes in the Turkana Dep e in (Cohen 1981; Frostick et al., 1986; Williamson and Savage, 1986; Frostick und Keid, 1987; Tiercelin et al., 2010; Hargrave et al., 2014; Nutz et al., 2017; Schuster -nd Nutz, 2018) stand as text-book examples of sedimentation in extensional basins, $x$ ith thick exposures of several hundred meters that provide a quasi-complete recc $\mathrm{d}$ or extensional basin evolution, especially during the PlioPleistocene, between $\sim 4.00$ nd $\sim 0.75$ million years (Ma). Well-exposed in distinct parts of the northern region of he i urkana Depression, the three formations of the Omo Group (de Heinzelin, 1983), i.e. the Shungura Fm, the Koobi Fora Fm and the Nachukui Fm, constitute exceptionally continuous archives from the three key domains of a half-graben system, i.e. the axial system, the ramp transverse system, and the border-faulted transverse system, respectively.

The three formations are also world-renowned fossil-bearing successions for paleoanthropology, paleontology and archeology. Dedicated investigations are ongoing since Arambourg's expeditions in the region (Arambourg 1935 and 1943) some 30 years after the 
trans-African expedition of du Bourg de Bozas that reported fossil vertebrates from the Lower Omo Valley (Boisserie et al., 2008).The Nachukui Fm happened to be particularly rich with, to date, $>100$ archaeological sites and $>500$ specimens of early hominins, some of which have been instrumental for the understanding of human evolution. These discoveries include specimens of Australopithecus anamensis, Kenyanthropus platyops, Paranthropus aethiopicus, Paranthropus boisei, Homo rudolfensis, Homo erectus and Homo sapiens (Brown et al., 1985; Walker et al., 1986; Leakey and Walker, 1988; Leakey et al., 1995, 2001; Prat et al., 2003, 2005). Numerous stone tools were also fornd in strata of this Formation (Roche et al., 1999; Delagnes and Roche, 2005), amo ig vnich the earliest evidence of Acheulean stone tool technology (Lepre et al., 2011) Nire recently, the Lomekwian stone tools found in strata of the Nachukui Fm pus'ec the first appearance of homonin technological behaviour back to 3.3 Ma (Han nd et al., 2015). In summary, the northern Turkana Depression is generally conside $\cdot{ }^{\circ} \mathfrak{d}$ key area to understand how paleoenvironmental change and human evolution are linke.' (Maslin and Trauth, 2009; Maslin et al., 2014; Potts and Faith, 2015; Cohen et al., 2015). Fr,r all these reasons, the Plio-Pleistocene sediments of the Turkana Depression, and $r$ rticularly the Nachukui Fm, are of uttermost importance for many communities within th॰ of osciences.

However, since he proneer work by Harris et al. (1988) on the Nachukui Fm, by de Heinzelin (1983) on the Shungura Fm, and by Brown and Feibel (1991) on the Koobi Fora Fm, none of the three formations of the Omo Group has been comprehensively investigated. Instead, a variety of local studies have been performed on each Formation, often in direct association with paleontological and archeological discoveries. In this review, we present a synthesis of recent investigations on the Nachukui Fm, which is the longest-lasting Formation of the Omo Group, and we refine conditions of sedimentation between $\sim 4.00$ and $\sim 0.75 \mathrm{Ma}$, in West Turkana and subsequently paleoenvironmental changes. For the first time, continuous 
and comprehensive reconstructions of i) paleolake fluctuation, ii) the evolution of sedimentary dynamics and related paleolandscapes and iii) the respective influence of various controlling factors (i.e., climate, tectonism) are proposed based on depositional environments analysis, sequence stratigraphy and paleovegetation in both the Omo Valley and West Turkana areas. Successive sedimentary systems are characterized revealing that variable sedimentary paleolandscapes alternated along the border fault (i.e., Murua Rith Lapurr Fault or MRLF) of the northern Turkana Depression between $\sim 4.00$ and $\sim 0.75 \mathrm{Ma}$. Confronting $\delta^{13} \mathrm{C}$ isotopic ratios in soil carbonates (Levin, 2015) and inferred tree cover ( $C_{t} \cdot$ ling et al., 2011) with our sedimentological interpretations; we unravel the relative int ence of climate and tectonism on paleolake fluctuations and paleolandscape evolution 1 - providing this synthesis we aim at documenting depositional processes in continental rift $\mathrm{L} \cdot \mathrm{sin}$, especially along faulted borders. We also aim at proposing a general framev $0_{1}^{\prime} r f$ paleoenvironmental reconstruction for further investigations in this area.

\section{GEOLOGICAL CONTEX}

\subsection{Regional structural entli:-o}

The Turkana Depression _; part of the East African Rift System (EARS), located between the Ethiopian and the East-African Domes (Fig. 1A). It corresponds to a $300 \mathrm{~km}$ long and $200 \mathrm{~km}$ wide lowland that separates the Main Ethiopian Rift to the north from the northern Kenyan rift to the south (Ebinger et al., 2000; Brune et al., 2017). The Turkana Depression consists of several N-S oriented half-grabens and grabens which developed from the middle to upper Eocene up to the present-day (Rosendahl, 1987; Dunkelman et al., 1988, 1989; Morley et al., 1999; Tiercelin and Lezzar, 2002; Vétel and Le Gall, 2006; Tiercelin et al., 2012a and 2012b; Macgregor, 2015; Boone et al., 2017, 2019; Ragon et al., 2019). 
The Turkana Depression is subdivided into a southern and a northern depression based on their different structural characteristics (Ragon et al., 2019). The southern Turkana Depression consists of five juxtaposed N-S oriented half-grabens known as the Naipa, Lokichar, Turkwel, Kerio and South Lake Basins (Fig.1B, C). Together they form a $>200 \mathrm{~km}$ wide rift system (sensu Buck, 1991), characterized by relatively low-lying reliefs due to limited shoulder uplifts in between the different basins. The onset of the extension related to the Cenozoic EARS started at around 45-40 Ma in the Naipa and Lokichar Basins (Boone et al., 2019). During the early Miocene (23-15 Ma), surface rurturt migrated farther east with the opening of the Turkwel and Kerio Basins (Vétel and Lf U'll, 2006). Later, the initiation of the South Lake Basin may have started slightly before 16 Ma (Morley et al., 1999; Vétel and Le Gall, 2006). In contrasts, the northern Turkara +'epression is strikingly different. It consists of a single $80 \mathrm{~km}$ wide and $>4 \mathrm{~km}$ de 决 A'jdelfettah et al., 2016) N-S oriented halfgraben (Hendrie et al., 1994; Morley $e_{\iota}$ al., 1999; Tiercelin et al., 2004; Vétel and Le Gall, 2006; Ragon et al., 2019) referred to ai the North Lake Basin (Fig. 1B, C). The North Lake Basin forms a narrow rift (sensu Pיch, 991) bounded to the west by the N-S oriented Murua Rith-Lapurr Fault (MRLF) (Fi , $_{\varepsilon}$ (C, 2), and to the east by a west-dipping ramp system. West of the MRLF, a relative hig:-r lief characterizes the rift shoulder referred to as the Murua Rith Hills and the Lapu ${ }^{-r}$ range (Fig. 2). East of the MRLF, the basin is affected by several smaller normal faults up to a second major one, i.e. the Shore Fault (Nutz et al., 2017; Ragon et al., 2019), as it is currently located at Lake Turkana's shore (Fig.2). In the northern Turkana Depression, the onset of the extension is delayed. It is associated with the development of micro-basins dated between $\sim 28$ and $\sim 25.5 \mathrm{Ma}$ (Ragon et al., 2019), during the first phase of extension attributed to EARS1 (sensu Macgregor, 2015). After a period of tectonic quiescence, a second pulse of extension referred to as EARS2 (sensu Macgregor, 2015), led to the opening of the North Lake Basin around 14 Ma (Boone et al., 2017; Ragon et al., 2019) 
and the onset of sedimentation in the basin. At $\sim 0.7 \mathrm{Ma}$, the shore fault (Fig. 2) became much more active than the MRLF, the depocentre shifted markedly eastward (Nutz et al., 2017) and this event marked the end, except locally, of the Nachukui Fm sedimentary system. The deposits of the Nachukui Fm subsequently constituted the footwall of the newly-formed and still active depocentre (Nutz et al., 2017), providing geologists with some of the remarkable outcrops presented hereafter.

\subsection{Regional lithological framework}

The basement of the northern Turkana Depression is mad of netamorphic Proterozoic rocks (Williamson and Savage, 1986; Morley et al., 1992; vic coit et al., 1993; Morley et al., 1999; Tiercelin et al., 2012b). The oldest sedimentarv r scks deposited on the basement are the Turkana Grits, locally known as the Lapur Sr"dsiune Formation, which correspond to fluvial sandstones from Late Cretaceous to Olis : ene age (Murray-Hughes, 1933; Arambourg and Wolff, 1969; Morley et al., 1999; Tierc:lin et al., 2004, 2012a and 2012b). Overlying the Turkana Grits, thick lava flows ron`munly associated with intercalated volcano-sedimentary rocks were deposited as a resnoı. e to intense fissural volcanic activity during Late Eocene to mid Miocene times, depr any of the location. They are referred to as the Turkana Volcanics Fm (Fig. 3; Bellieni et a.', 1981, 1987; Zanettin et al., 1983; McDougall and Brown, 2009; Rooney, 2017). The $3 \mathrm{~km}$ thick Turkana Volcanics Fm is spread over an extensive region, including the West Turkana area (Fig. 3). In West Turkana, the Turkana Volcanics Fm is Upper Eocene to Lower Oligocene in age and predates rifting (Ragon et al., 2019). Overlying the Turkana Volcanics Fm, Oligocene sedimentary rocks were deposited in extensional microbasins (Ragon et al., 2019); they fill the oldest syn-rift structures in this area. Upwards in the succession, Miocene rocks are exposed sparsely, but they have been identified in some wells (Schofield et al., 2020) suggesting deposition at least in the North Lake Basin after its 
opening $14 \mathrm{Ma}$ ago. Overlying, Plio-Pleistocene sediments of the Omo Group are exposed all around modern Lake Turkana. The Omo Group, first defined by de Heinzelin (1983), is subdivided into three main formations referred to as the Nachukui, Koobi Fora and Shungura fms cropping out in the western Turkana, eastern Turkana and Omo Valley, respectively (Fig. 1B), and two additional minor ones referred to as Usno and Mursi Fms both exposed in the Omo Valley. Younger sediments are included in the Turkana Group (Feibel, 2011), such as the Kibish Fm (Butzer, 1971) and the Holocene Galana Boi Fm (Owen and Renaut, 1986), which unconformably covers sediments of the Omo Group (Fig. 3).

The Nachukui Formation is located in the West Tu Ka`a area and represents a $>700 \mathrm{~m}$ thick succession of fossil-bearing fluvial-deltaic-lacıstrine sediments (Harris et al., 1988; Feibel, 2011). This formation is divided into 8 memrers separated by tuff horizons. It spans a time interval ranging from $\sim 4.00$ to $\sim 0.75 \mathrm{Ma}$ na',ed on tephrostratigraphy (Brown et al., 2006; McDougall et al., 2012). Exposur - a e located eastward of the MRLF and westward of the Shore Fault (Fig. 2).

During the Plio-Pleistocene sc v'ral volcanic events occurred in the northern Turkana Depression and episodic volca: ic material intercalated in sediments of the Nachukui Fm. The Gombe Basalt, which is mara sf extensive and thick basaltic lava flows corresponds to an important volcanic eve. ${ }^{+}$lindt occurred between 4.29 and 4.18 Ma in the north (Erbello and Kidane, 2018) and that persisted southward at least until 3.95 Ma (Haileab et al., 2004; Bruhn et al., 2011). Less widespread, the Kulal Volcanics (dated from $\sim 3.00$ to $\sim 2.20 \mathrm{Ma}$ ) and the Lenderit Basalt (dated from $\sim 2.20$ to $\sim 2.00 \mathrm{Ma}$ ) were emplaced mostly in the southeastern part of the northern Turkana depression (Bruhn et al., 2011). Postdating the Nachukui Fm, other volcanic events are at the origin of the North, Central and South islands of Lake Turkana (Brown and Carmichael, 1971; Karson and Curtis, 1994). 


\section{METHODS}

\subsection{Field analysis}

Four field surveys were conducted in July 2014, November 2014, July 2015 and July 2016. Eighteen composite sections were measured along river incisions (Fig. 4) and multiple panoramas were analyzed (see Table S1 for detailed locations). We logged sections spanning the time interval between $\sim 4.00$ and $\sim 1.25 \mathrm{Ma}$. The interval between $\sim 1.25$ and $\sim 0.75 \mathrm{Ma}$ was not logged by authors but we used information provided by in ?ris et al., (1988). Sections were measured using a Jacob's staff and we consider a $+/-$, no/ potential error about strata thicknesses. Sedimentary facies were interpreted based on macroscopic examinations during field surveys. Lithology, grain size, sorting, bed hir kness, sedimentary structures, and paleocurrents were assessed based on conver ti st al facies analysis (Table 1). Measured sections were correlated based on tephro nrı nolugy (Table 2) or through the physical tracing of prominent stratigraphical surfaces within the basin. Subsequently, sequence analysis was carried out. Sequence stratigraphy a $m$, at deciphering cyclicity in sedimentation due to variations in base level (i.e., lak 2 svel in this case), flux of sediment supply and/or subsidence rate (Catuneanu, 2018). In this : udy, we use the model of Trangressive-Regressive sequence (Johnson and Murphy, 1: 84. Embry and Johannessen, 1992) in order to reconstruct trajectory of the shoreline through ıme and thus paleolake extensions and contractions. TransgressiveRegressive sequences (T-R sequence) were delineated by considering each sequence as a full cycle of change in the accommodation space, involving an increase due to the landward migrating shoreline during lake level raise followed by a decrease in the space available for sediments to fill associated with the basinward migration of the shoreline due either to lake level fall or sediment wedges progradations. In this model, a sequence is bounded by maximum regressive surfaces that form the Sequence Boundary (SB). The transgressive part includes sediments deposited during the transgression while the regressive part comprises 
sediments deposited during the highstand normal regression, the forced regression and the lowstand normal regression (Catuneanu, 2018). The T-R sequence model reflects successive lateral shoreline migrations, landward during the transgressive part and basinward during the regressive part of the T-R sequences. As a consequence, this model highlights paleolake extensions/contractions rather than changes in water depth. In places, several remarkable stratigraphic intervals or surfaces are interpreted such as Maximum Flooding Intervals (MFI) and Wave Ravinement Surfaces (WRS) according to Catuneanu (2018)..

\subsection{Chronological constraints}

Our chronological framework is established based or $w_{1} h_{1}$ ochronology using a dataset of 21 dated volcanic tuffs, many of which have been iden.ffieu throughout the area from their geochemical signatures. Tuffs were collected du^ing iugging (Table 2). The chemical composition of 18 tephra layers was analyzed usm_ a microprobe (CAMECA SX-FIVE, CAMPARIS service, Paris 6 University) to measure at 'ndance of $\mathrm{Fe}_{2} \mathrm{O}_{3}, \mathrm{CaO}$ and $\mathrm{K}_{2} \mathrm{O}$ oxides and $\mathrm{Mn}$ and Ti elements. Three tuffs were not aı ?lyzed as they had been identified previously by Lepre $e t$

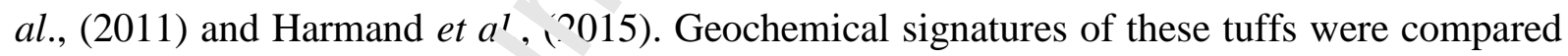

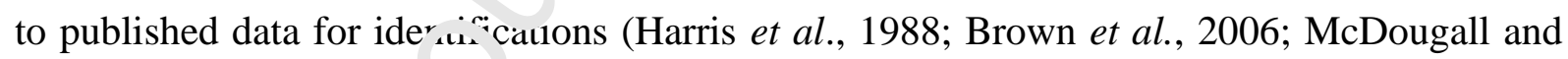
Brown, 2008). The $18 t_{1}$ hra layers recognized in our sections were identified as 16 distinct tuffs, for which absolute ages estimated by K-Ar and Ar-Ar methods were then obtained from the literature (Pickford et al., 1991; Lepre et al., 2011; McDougall et al., 2012; Harmand et al., 2015; Boës et al., 2018).

\subsection{Pedogenic $\delta^{13} \mathrm{C}$ record and inferred paleovegetation changes}

Plant fossils are rare in Formations of the Turkana Depression, but an important dataset of carbon isotopic measurements was acquired over the years (Cerling, 1999; Harris and Leakey, 
2003; Wynn, 2004; Bobe et al., 2007; Levin et al., 2011) and recently compiled by Levin (2015). The ${ }^{12} \mathrm{C} /{ }^{13} \mathrm{C}$ ratio measured in soil carbonates (or $\delta^{13} \mathrm{C}_{\text {soil }}$ carbonate) reflects the proportion of plant biomass using $\mathrm{C}_{3}$ or $\mathrm{C}_{4}$ photosynthesis pathways (Cerling and Quade, 1993). In the tropics, $C_{3}$ plants are predominantly trees and shrubs (and aquatic and montane grasses in a lower proportion), while $\mathrm{C}_{4}$ plants are predominantly lowland grasses, sedges, and the often overlooked xerophytic and salt-loving shrubs and forbs of the Amaranthaceae family (Tieszen et al., 1979; Sage, 2004). $\delta^{13} \mathrm{C}$ in soil carbonates, therefore, has been used to approximate the prevalence of woodlands and grasslands, and 心 quantify changes in the proportion of woody cover through time. $\delta^{13} \mathrm{C}_{\text {soil carbonate }} \mathrm{va}$ ' indicate vegetation with $>40 \%$ woody cover (such as tu. ast and undifferentiated woodland, shrubland or bushland) and values $>-7 \%$ indicate nu-e open vegetation (such as wooded grasslands and grasslands) (Cerling et al., 2011).

Woody cover can in turn be usec as $\lrcorner$ proxy of climate as more rainfall and/or shorter dry seasons favor denser woody cover 'Staver et al., 2011). In the arid Turkana Depression, dense tree cover predominantly ${ }^{\circ} \mathrm{cu} \cdot \mathrm{s}$ in the alluvial plain along the Omo River, where a shallow water table sustain $\_$perennial riparian woodlands and forests (Carr, 1998). Considering that the amoun of groundwater available in alluvial plains is controlled by the activity of rivers, then. eıves dependent of rainfall over river catchments, wetter periods should be associated with more important woody cover (forest, woodlands) in opposition to drier periods which should be characterized by less abundant woody cover (grasslands or steppes). To approximate climate change, namely change in rainfall over river catchments, we therefore used $\delta^{13} \mathrm{C}$ in soil carbonates. We considered altogether the paleosoil data from Nachukui Fm $(n=130)$ to illustrate paleovegetation changes in the West Turkana area and paleohydrological fluctuations in river catchments of the western rift shoulder (between 3.9 and 0.9 Ma). Data from the Shungura Fm $(n=49)$ were considered independently to illustrate 
paleovegetation and paleohydrological changes in the Ethiopian Highlands and the Omo River catchment (between 3.20 and 1.25 Ma). Subsequently, we compared the reconstructed paleolake extension with woody cover changes in the both West Turkana and Omo Valley areas. In case of matching between periods of lake highstand and important woody cover or conversely between periods of lake lowstand and low woody cover, lake highstands and lowstands are coeval with wet and dry periods in river catchments, respectively, revealing that climate is the dominant parameter controlling water-level fluctuations. In contrast, in case of a lake highstand occurring contemporaneously with a reduced wnna, cover in both Omo Valley and West Turkana, climate in the considered region can oc discarded to explain paleolake fluctuations.

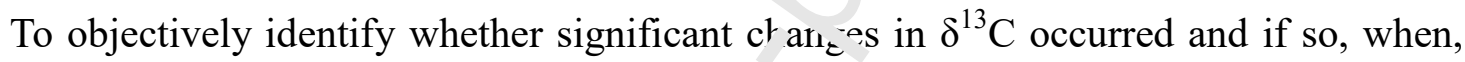
we have developed a new automatic classifica'ic $r$.ethod based on $k$-means clustering (Bell, 1978; Grim, 1987; Wagstaff et al., .00 ). K-means clustering aims at partitioning $n$ observations into $k$ clusters in which $\mathrm{e}_{\mathfrak{a}} \mathrm{h}$ observation belongs to the nearest cluster. Clusters are selected as such to minimize the variance within clusters (group highly similar observations) and to maxim: e variation among clusters (differentiate distinct groups). Applying this method to timı sf ries data, temporal overlap was not permitted among clusters and each cluster repre alıs a particular period bounded by the oldest and the youngest observations within the cluster. A centroid is estimated for each cluster, defined by the mean age and the mean value of $\delta^{13} \mathrm{C}$ of all observations included in a given cluster; centroids are linked forming curves that reflect changes of $\delta^{13} \mathrm{C}$ isotopic ratios in soil carbonates through time. The $k$-means method usually requires the number of clusters to be arbitrarily selected prior to analysis, for example using Elbow methods (Bholowalia et al., 2014) or principal component analysis (PCA). For this study, we did not arbitrarily set the number of groups $a$ priori to avoid subjective association of observations into artificial time slices. Instead, we ran 
12 classifications with a number of clusters ranging from 4 to 15 . Considering the 12 classifications, we calculated a total of 114 centroids. In each classification, centroids of groups including at least $3 \%$ of the observations were considered representative. Representative centroids were then stacked and linked to reconstruct general changes in the $\delta^{13} \mathrm{C}$ isotopic ratios in soil carbonates through time. The confidence interval for each centroid is represented by an envelope that depends on the total variance within the cluster divided by the number of observations included in the cluster.

\subsection{Accommodation and shoreline trajectory}

As defined by Catuneanu (2018), accommodation (A, is the space made available for potential sediment accumulation. It derives frrm sea/lake-level changes and rates ofsubsidence/uplift or a combination of these $x$ - ce'ses. Variations in accommodation during a given time interval $(\delta \mathrm{A})$ result fr $\boldsymbol{\eta}$ shanges in base-level combined with vertical movements of the basin substratum (1... subsidence) during this time interval. The ratio of accommodation rate/rate of sedimant "sply or $\delta \mathrm{A} / \delta \mathrm{S}$ ratio is considered to directly drive the trajectory of the shoreline. $\mathrm{V}$, hen $\delta \mathrm{A} / \delta \mathrm{S} \leq 0$, erosion occurs, progradation (i.e., basinward migration of the shoreline) $\omega^{\cdots}$.rs when $0<\delta \mathrm{A} / \delta \mathrm{S}<1$ (i.e., $\delta \mathrm{S}$ exceeds $\delta \mathrm{A}$ ), aggradation (i.e., stabilization of the sho, $l_{11 \mathrm{c}}$ ) when $\delta \mathrm{A} / \delta \mathrm{S}=1$ and retrogradation (i.e., landward migration of the the shoreline) when $\delta \mathrm{A} / \delta \mathrm{S}>1$ (i.e., $\delta \mathrm{A}$ exceeds $\delta \mathrm{S}$ ). Hence, with a constant rate of sediment supply $(\delta \mathrm{S})$, variation in accommodation space $(\delta \mathrm{A})$ controls the establishment and rates of progradation and retrogradation dynamics and the corresponding regressive and transgressive trends, respectively. The higher $\delta \mathrm{S}$ compared to $\delta \mathrm{A}$, the faster is the progradation, the higher $\delta \mathrm{A}$ compared to $\delta \mathrm{S}$, the faster is the retrogradation. Conversely, with constant rate of variation in accommodation $(\delta \mathrm{A})$, variation in sediment supply $(\delta \mathrm{S})$ drives 
the establishment and rates of progradation and retrogradation dynamics and the corresponding regressive and transgressive trends.

On a vertical section, variations in accommodation during a given time interval is quantified by summing up the decompacted thickness of sediments (according to Sclater and Christie, 1980) deposited during this considered time interval and the variations of paleobathymetry/paleoaltitude from $\mathrm{T}_{0}$ to $\mathrm{T}_{1}$ (Jervey, 1988). Hence, evaluating variations in accommodation requires (1) absolute datums across the section, (2) lithological data and (3) estimations of paleobathymetry/paleoaltitude along each datume ine identification of tuffs in sections of the Nachukui Fm provides chronologically-c sns 'raned sediment intervals. The averaged lithology of each interval (i.e. percentages of sa. $\mathrm{f}$ and mud between two datums) is obtained from sedimentological analysis of the sectirns 'Fig. 4) and thicknesses are then corrected for compaction. Estimations of paleoba $h_{j} n f$, ry/paleoaltitude result from facies analysis and are indicated in comparison with he ake level noted 0 . In this study, a paleobathymetry of $25 \mathrm{~m}$ is attributed to offshore en ironments, $10 \mathrm{~m}$ to transitional environments, $5 \mathrm{~m}$ to shoreface sediments, 0 to beach ervir $n$. nents and a paleoaltitude of $10 \mathrm{~m}$ to fluvial plain and $20 \mathrm{~m}$ to alluvial fan. Here, a $\rightarrow$ mpusite curve is reconstructed to represents the variation of accommodation between $\sim 4 . \mathrm{\imath}^{2 n} \cdot$.nd $\sim 1.28 \mathrm{Ma}$.

\section{RESULTS}

\subsection{Facies associations}

Five main facies associations (FA) are identified in the Nachukui Fm from $\sim 4$ to $\sim 1.25 \mathrm{Ma}$ revealing the existence of five groups of depositional environments (Table 1). Offshore (FA1) and transitional (FA2) deposits consist mostly of mudstone (i.e., pelites). In contrast to FA1, FA2 shows recurrent intercalated coarser grained beds, which we interpret as storm deposits, 
indicating sedimentation in the transition zone (Coe et al., 2003) Wave-influenced nearshore (FA3) deposits are dominated by very well- to well-sorted sandstone, bioclastic sandstone to rudstone with bioclasts corresponding mainly to shells or shell fragments of aquatic mollusks. Within FA3, we recognize three sub-groups: the shoreface (FA3-a), the beach (FA3-b) and the backshore (FA3-c). River-dominated nearshore (FA4) deposits are mixed clastic and carbonate material deposited into coastal alluvial systems. River (FA5) deposits consist of mudstone, sandstone and conglomerate reflecting deposition attributed to the activity of river systems in the subaerial domain. Within FA5, two sub-environmen are identified in FA5: the alluvial plain (F5-a) and alluvial fan (F5-b) sub-environme .ts.

\subsubsection{Offshore deposits (FA1)}

Sediments of FA1 are made of blackish, $\vdash_{\wedge} v^{\prime} n_{\llcorner} h$ or greenish mudstone (Fig. 5A), depending on the locations. Prevailing sedimentary st dctures consist of $\mathrm{mm}$ - to $\mathrm{cm}$-scale horizontal laminations (Fig. 5B), even if $\mathrm{cm}-\varepsilon_{\mathrm{s}} \mathrm{c}^{\mathrm{l}} \mathrm{Jw}$-angle ripple laminations are observed in places (Fig. 5B). Mudstones are comm $n$ nly intercalated by dm- to $\mathrm{m}$-thick massive diatomite beds (Fig. 5C). Occasionally, isolan dm- to m-thick tabular or lenticular massive or normalgraded sandstone bers c rara terized by erosive bases are embedded in mudstones (Fig. 5D). In places, such sandstc $n$, beds are sources for m-scale dyke-type donwtapering intrusions. Aquatic vertebrate remains such as fish bones and teeth are common in FA1.

Both mudstones and diatomite reflect suspension fallout from settling processes of fines in subaqueous low-energy depositional environments (Scholle, 1971; Boulesteix et al., 2019), even if occasional ripple laminations in mudstones suggest occasional occurrence of tractional currents. Predominance of settling processes reflects a depositional environment below both the fair-weather and the storm wave bases that define the offshore domain (Coe et al., 2003). Occasional evidences for tractional current in mudstones are attributed to 
occasional bottom currents that can occur relatively frequently in offshore lake environments (e.g., Nutz et al., 2014, 2015a, 2018). Isolated massive sandstone beds indicate debris-flow deposits (Talling et al., 2012). Intercalated in offshore mudstones, these debris flows can be attributed to either river-derived underflows or mass-wasting turbidity currents that are frequent processes in deep portions of lakes (e.g., Zavala et al., 2010; Nutz et al., 2014). However, the occurrence of normal graded beds with only sparsely observed inverse graded intervals rather suggests mass-wasting gravity flows (Mulder et al., 2003). Subsequently to their deposition, sandstone beds are occasionally parent units .7r injectites that may be conservatively attributed to seismicity (Hurst et al., 2011) $\boldsymbol{r}^{2} \mathrm{~V}$ V1ous estimates based on wave observations on modern Lake Turkana broadly support a _torm wave base at a depth of $\sim-20$ $\mathrm{m}$ (Nutz et al., 2017). Thus, FA1 is considered to refle - sedimentation in the lake, at $>20 \mathrm{~m}$ of depth.

\subsubsection{Transitional deposits (FA2)}

Sediments of FA2 consist of $\mathrm{cm}$ to cin-scale thick coarse-grained beds made of sandstone or shells that alternate with mua ${ }^{\text {tolı }}$ intervals similar to those observed in FA1. Two types of intercalated coarse-grain $: d t$ ds are identified. The first type of FA2 corresponds to dm-thick sandstones beds (Fig. 5E . Where internal primary sedimentary structures are obvious, their lower boundary is erosional, in places marked by aligned $\mathrm{mm}$ - to $\mathrm{cm}$-scale gravels and pebbles. Overlying their lower boundary, coarse sandstones are horizontally laminated grading upward to medium sandstones in symmetric ripple laminations (Fig. 5E) showing a general fining-up interval. In places, the top surface show preserved cogenetic interferent ripples (Fig. 5F) organized in brick and tiles pattern (Allen, 1982). The second type of coarsegrained beds in FA2 consists of cm-scale thick erosionally-based beds (Fig. 5G) of shell 
assemblages, either consisting of entire gastropod shells or fragments, forming massive packstone beds (Fig. 5H).

Similar to FA1, mudstone intervals separating coarse beds reflect subaqueous lowenergy depositional environments characterized by predominant suspension fallout of fines from settling processes. Embedded sandstone beds marked by basal erosion associated with a fining-up trend indicate sedimentation from a high-density gravity flow (Talling et al., 2012) and represent event beds (Seilacher, 1982). In the upper part, cogenetic interferent ripples evidence influence of interfering oscillatory currents during the $w$ ?ning of the flow (Aigner, 1985; Jelby et al., 2019). In FA2, these sandstone beds are III `rpreted as storm beds (Johnson and Baldwin, 1996; Jelby et al., 2019). The second tvw of coarser beds reveals en masse sedimentation (Talling et al., 2012) of shells or s'ie fragments suggesting that repeated currents reworked shells in the nearshore dom $\lambda_{1}$ to transport them to areas between the fairweather and the storm wave bases. 7 hur, shelly coarse beds embedded in subaqueous mudstones are also attributed to stc-m-induced currents. Non-amalgamated tempestites usually form at depths between the $; i$ weather and the storm wave bases. Considering a storm wave base around -20 $\mathrm{n}$. and d fair-weather wave base at around $-5 \mathrm{~m}$ in modern Lake Turkana (Nutz et al., 2017). ㄴe cransitional depositional environment is here estimated within water depths of 5 to 20. ?

\subsubsection{Wave-influenced nearshore deposits (FA3)}

\section{Shoreface deposits (FA3-a)}

FA3-a deposits consist of well-sorted medium to coarse sandstone alternating in places with dm-scale packstone to rudstone beds composed of freshwater gastropod and bivalve shells in 1-10 m thick packages. Mollusk specimens are typically rolled and somewhat abraded, with the valves of bivalves regularly being separated. Planar laminations and wave ripple 
laminations (Fig. 6A, B and C) prevail even if occasional dm-scale beds with planar crosslaminations are observed. In places, heavy minerals are abundant and concentrated in dark laminations (Fig. 6A). Occasionally, dm-scale sandstone beds laterally varying in thickness at m-scale distances reveal hummocky cross-stratifications (HCS) (Fig. 6D). Vertical burrows are common. When observed on large exposures, such sediments are included in 2 to $10 \mathrm{~m}$ thick wedges that comprise large-scale oblique master beds gently dipping towards the basin (Nutz et al., 2017).

Predominance of mollusks in bioclastic sandstone and na ${ }^{1}$ stone suggests nearshore environments. Rolled and somewhat abraded shells, with it valves of bivalves regularly being separated reveal a relative high-energy environment . hile wave-ripples reveal oscillatory currents. Associated with planar laminations, sedimer.ta "' structures reflect a deposition in the nearshore domain either in the surf or the swash on : (Clifton et al., 1971; Massari and Parea, 1988; Clifton 2006). Occasional planar _ "os s-laminations reveal dunes attributed to tractional currents in the build-up or surf zones 'Clifton et al., 1971; Massari and Parea 1988) while HCS indicate the combination of $\ln \operatorname{rgc}-\approx$ ale oscillatory and tractional flows developed during storm events in the shoreface ( Jarnıs et al., 1975; Dott and Bourgeois, 1982). Packstone and rudstone beds support a dep cition in coastal domains. Finally, altogether these sedimentary structures evidence seci $\eta t_{n}$ tation in a wave-dominated shoreface depositional environment. Large-scale and low-angle master beds are interpreted as clinoforms revealing basinward progradations of coastal wedges (Nutz et al., 2017). The shoreface domain is located between the fair-weather wave base and the foreshore and corresponds to that part of the shorezone where sediments are constantly agitated by waves. This interval is broadly estimated between -5 and -2 $\mathrm{m}$ in depth (Nutz et al., 2017). 
Depending of their location, FA3-b deposits consist of fine conglomerate, coarse sandstones, bioclastic sandstone, packstone or rudstone beds (Fig. 6E and F) composed of freshwater mollusk shells. Mollusk specimens are abraded and with the valves of bivalves are regularly separated. Two types of foreshore deposits are distinguished in measured sections. The first type of FA3-b is included in 1 to 2 -m-thick sediment bodies made of planar laminations in low- $\left(<5^{\circ}\right)$ to moderate-angle $\left(5-10^{\circ}\right)$ oblique master beds dipping basinward (Fig. 6G, H). The second type of FA3-b consists of bioturbated coarse sandstone or bioclastic sandstone included in successive dm- to m-scale intervals. Each interva1 is haracterized in the lower part by horizontal laminations with occasional planar and IIt 'igh cross-laminations with few burrows or rhizoliths. The abundance of such burrows or . hizoliths increases in the upper part which is pervasively bioturbated. Primary structures $\mathrm{Su}^{-\mathrm{h}}$ as planar or cross-laminations, are disrupted and not obvious anymore. The upp $r$, ar is topped by an irregular surface where burrows or rhizoliths are interrupted (Fis 6J).

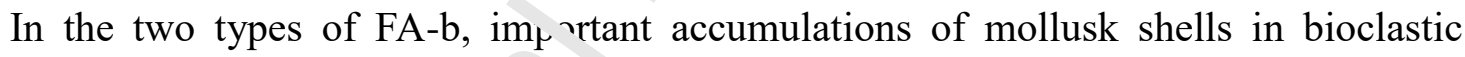
sandstone, packstone and rudstone ev d nce sedimentation in the coastal domain. In the first type, oblique master beds are i: terpieted as reflecting the accretion of successive beach faces (Dabrio, 1982; Tamura, 201 <, d veloped in the swash zone (Clifton et al., 1971) supported by the abraded shell assen hlages that suggest the influence of waves. Low-angle master beds express relative high-energy dissipative beaches in a high-energy wave-dominated foreshore environment. Higher-angle oblique stratifications rather indicate more reflective beaches developed in a moderate-energy wave-dominated foreshore environment (Wright et al., 1979). In the second type of FA3-b, the abundance of bioturbation reflects deposits from a lowenergy shore environment where aquatic macrophytes were abundant and fairly impacted by waves. This type reflects sedimentation in a more sheltered zone, such as coastal swamps that experienced alternations between sedimentation and the development of vegetation. Both 
versions of FA3-b represent a sedimentation in a foreshore depositional environment, which bathymetric range is broadly estimated between -2 and $0 \mathrm{~m}$ (Nutz et al., 2017), corresponding to the swash zone in wave-influenced nearshore domains or to areas where bathymetry allowed aquatic macrophytes to develop.

\section{Backshore deposits (FA3-c)}

FA3-c deposits mostly consist of well-sorted medium sandston in dm-scale beds alternating with bioclastic sandstone beds. These beds are included in $1-2 \mathrm{~m}$ thick sediment bodies (Fig. 7A), which show large-scale high-angle $\left(>10^{\circ}\right)$ oblique nasir beds dipping toward the basin margin, in places grading updip to sub-horizontal bc. 's. ग Iaster beds are frequently reworked revealing recurrent reactivations (Fig. 7A). C(m $n$ )nly, the uppermost sub-horizontal beds display dm-scale burrows and rhizoliths $\rho v u_{1} \geq e_{\iota}$ tl., 2017).

Mollusk shells in bioclastic s?ndston master beds reveal migrating featur $\mathrm{s} n$ the central portion of the basin toward the margin whereas sub-horizontal beds ir ie uppermost part reflect coeval aggradation. In nearshore domains, m-scale landward-n; grating features are interpreted as washover fans (e.g., Schwartz, 1982; $\mathrm{Ne}^{\urcorner}$c $^{+} a$, 2003; Baumann et al., 2017; Nutz et al., 2017). Internal reactivation surfaces ar soil development at the top of sediment bodies indicate intermittent migration and distinct construction phases. During storm episodes, infragravity waves transport sediments from the foreshore to the backshore domain forming washover accumulations (Baumann et al., 2017). Between two successive storms, soils developed on top surfaces (Nutz et al., 2017). Washover fans are important features along wave-dominated coasts of lacustrine systems (Nutz et al., 2018). In the Turkana Depression, early Quaternary, Holocene and modern examples of washover fans are abundant (Tiercelin et al., 2010; Nutz et 
al., 2017; Schuster and Nutz, 2018). They formed broadly between 1 and $5 \mathrm{~m}$ above the contemporaneous lake level.

\subsubsection{River-dominated nearshore deposits (FA4)}

FA4 deposits are represented by two different types. The first type of FA4 consists of poorlysorted fine to medium matrix-supported conglomerates in $\mathrm{dm}$ - to m-thick beds. Matrix consists in sandstone, bioclastic sandstone and packstone inc . ling mollusk shells or shell fragments (Fig. 7B, and C). These beds are systematically in rc? ated in river deposits (FA5; Fig. 7C and D). Conglomerate clasts are relatively imr atu. whereas the matrix commonly includes planar laminations and wave ripple laminaı गns in sands, frequently associated with shells or shell fragments accumulations. Frequ $\mathrm{n}^{4} \mathrm{y}$ thin concentric carbonate laminae coat conglomerate clasts to form $\mathrm{cm}$ - to $\mathrm{dm}$ - , $\mathrm{ca}$ e 1s slated oncolites (Fig. 7C and D). In places, adjacent oncolites form clast-support-d congiomerates, topped by $\mathrm{dm}$ - to $\mathrm{m}$-thick continuous beds made of upward growing dome sa natolites (Fig. 7E). The second type of FA4 deposits corresponds to intervals of sev ral meters including $\mathrm{dm}$ - to m-scale very well-sorted sandstone beds that are either ta ular of channelized with erosional lower boundaries (Fig. 7F, G) separated by $\mathrm{d} \eta$-s ale massive mudstone beds. Sandstones beds include planar laminations, occasional :'smbing-ripples and rare dm-scale cross-laminations.

In the first type, mollusks in bioclastic sandstone and packstone indicate nearshore environments while wave ripples and oncolites suggest the recurrent influence of waves. The poor sorting of conglomerates and sandstones and the low maturity of pebbles suggest the absence of coastal transport. As such, fluvial tributaries that supplied sediment in the lake were close to depositional areas. This type of FA4 therefore derives from gravity flows in the form of hyperconcentrated flows (Mulder and Alexander, 2001) and/or from debris flows (Talling et al., 2012) that were subsequently partially reworked by waves forming fluvial- 
induced deposits in the nearshore domain. During river-flood, rivers generated flows that directly entered the lake and deposited coarse sediments in the nearshore domain forming mouth bar complexes. Waves then partially reworked previously deposited material and mixed river-derived sediments with in situ biogenic carbonate nearshore deposits (i.e., mollusk shells and microbialites). This type of FA4 includes coastal alluvial fan deposits. In places, long-term abandonment or avulsion of river channels allowed washing and sorting of oncolites by waves and subsequent development of thick carbonate intervals made of domal stromatolites (Fig.7E). The development of the carbonate inter 'al stopped when alluvial sedimentation restarted. The second type of FA4 dep usi's characterized by tabular or channelized sandstone beds reveals sedimentation in $\mathrm{t}_{\mathrm{h}}$, form of unconfined or confined turbulent flows, respectively (Wright 1977). Stackin c $_{\text {. }}$ several sandstone beds separated by dm- to m-scale mudstone intervals suggest re su. er. flows that broadly affected broadly the same areas. This suggests the proximi v f river mouths where river floods might have repeatedly generated hyperpycnal flow that supplied sands in the nearshore domain forming river mouth complexes. Finally $\mathrm{bc}^{\text {th }}$ types of FA4 are interpreted as river-dominated nearshore deposits.

\subsubsection{River deposits (FA5}

\section{Alluvial plain (FA5-a)}

FA5-a deposits consist of tens of intervals of $>10 \mathrm{~m}$ thick composed of sandy mudstone to muddy sandstone. These deposits include lenticular sediment bodies that are tens to hundreds of meters wide and meters thick, made of fine to medium conglomerates or coarse sandstones (Fig. 8A and B). In sandy mudstones to muddy sandstones intervals, primary depositional structures are difficult to observe, yet crude horizontal stratification seems to prevail. Pervasive termite nests are observed (Fig. 8C), in places connected to each other (Duringer et 
al., 2007). Occasional ant galleries also occur (Tiercelin et al., 2010). Embedded lenticular sediment bodies are erosion-based, showing dm- to m-scale trough cross-laminations (Fig. 8D) broadly oriented basinward. Occasionally, matrix-supported fine conglomerates in dmscale fining-up intervals are observed (Fig.8E). Bioturbation is frequent in the form of rhizoliths (Fig. 8F and G).

Sandy mudstones to muddy sandstones reflect deposition from both suspension fallout and tractional currents. The abundance of rhizoliths and social insect nests indicates terrestrial areas stable enough for recurrent soil development (plant gruvth and activity of soil organisms). Sandy mudstones to muddy sandstones ref.ec. aeposition of overbank fines during river overflows. During river overflow, sand is deposited on the alluvial plain. Subsequently, just after the peak of flood when the alıvial plain is flooded, mud deposited. Between two river flood events, soils develop $d$ iat resulted in homogenization of previously deposited muds and sands to form the ' $\mathrm{u}^{\prime}$ iently observed mixture of sandy mudstones to muddy sandstones. In coarse lenticular rediment bodies corresponding to channels infill, dmto m-scale through cross-stratificatior ? uggest migrating dunes and bars revealing tractional currents attributed to dilute flu vs auring lower flow regime conditions (Allen, 1964, 1982). The occasional occurrence of ining-up intervals evidence occasional sedimentation from gravity flows while thu nıssence of a muddy matrix suggests sedimentation from cohesive debris flows (Blair and McPherson, 1994, 2009). The large-scale lenticular geometry reveals that both dilute and debris flows were confined in wide and shallow channels. Finally, FA5-a deposits are interpreted to represent infill of braided river channels (Allen, 1964; Blair and McPherson, 1994); the broadly eastward directions of paleoflows suggest channels originating from the western rift shoulder. Thus, overbank deposits laterally associated with alluvial channels indicate organized stream flows that reflect alluvial plain systems (Miall, 1996; Bridge, 2003). 
Alluvial fan (FA5-b)

FA5-b are included in tens of meters thick and hundreds of meters wide sediment packages. Two types are distinguished. The first type of FA5-b is dominated by successive m-thick intervals of matrix-supported coarse conglomerate separated by $\mathrm{dm}$ - to m-scale beds of sandstones to fine conglomerates (Fig.8H). Coarse conglomerates show clasts ranging from pebbles up to boulders (Fig. 8I) while matrix corresponds to mindy coarse sands and gravels. Conglomerates are mostly massive even if faint horizont ll lá ninations are occasionally observed. Intercalated, $\mathrm{dm}$ - to $\mathrm{m}$-scale sandstones and $\mathrm{t}$, $\mathrm{e}$ onglomerates are moderatelysorted in horizontal stratifications. Common dm-sca e lo ig rhizoliths are observed, affecting all lithologies. The second type of FA5-b consi in of dm-scale planar beds made of poorlysorted coarse sandstones intervals sharply $-^{-1}$ tt , nating with fine conglomerates intervals (Fig. 8J). Faint horizontal laminations prevail in . 11 lithologies, in places associated with dm-scale trough-cross laminations. Locally, $\Perp$ :-scale intervals of medium conglomerates showing oriented and imbricated clasts are 1.tercalated. Even if rhizoliths are also observed, their abundance is lower compared in that in the first type.

In the first typ ${ }^{\prime}\left(f F_{A} 5-b\right.$, massive matrix-supported conglomeratic intervals reflect debris flows (Blair and McPherson, 1994, 2009) whereas occasional intercalated sandstone beds indicate occasional deposition from dilute flows during upper flow regime conditions (Allen, 1964; 1982). Rhizoliths suggest repeated and durable interruptions of flows favoring vegetation development during non-depositional periods. The second type of FA5-b reveals a sedimentation dominated by tractional currents from dilute flows during upper flow regime conditions (Allen, 1964; 1982). In places, sedimentation that originated from dilute flows is associated with sedimentation from concentrated to hyperconcentrated flows (Mulder and Alexander, 2001). In both types, the rarity of channelized features and occurrence of sheet 
form deposits evidence unconfined flows typical for sedimentation in alluvial fan systems. The first type is dominated by debris flows while the second type suggests sedimentation rather dominated by sheetflood processes (Blair and McPherson, 1994, 2009; Leleu et al., 2005, 2009).

\subsection{Sequence stratigraphy and high-amplitude paleolake fluctuations}

Following the interpretation of depositional environments (FA1-F:5) and observation of their stacking patterns (Figs. 4, 9, 10, 11, 12), we delineated $\div$ Q sequences over the complete

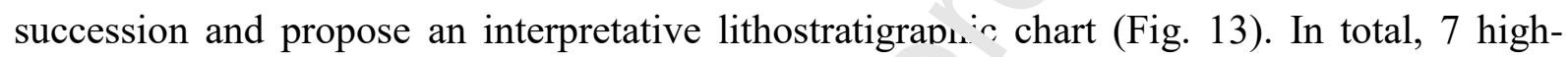
amplitude sequences (S1-S7) are delineated from $\sim 00$ to $\sim 1.25 \mathrm{Ma}$. Their limits and compositions are presented hereafter.

Directly overlaying the Gombe Basalt, $t_{1}$, succession starts either with alluvial fan deposits (FA5; sections 1, 2, 3 and 4) or offshore nudstones (FA1; section 5). In section 2, alluvial fan deposits are then overlain by 3-5 $\ldots$ thick transitional deposits whereas in sections 1,3 and 4 , they are directly overlain by $>10 \mathrm{~m}$ thick offshore lacustrine deposits. Offshore lacustrine deposits grade upward to $: 4_{1 .}$ thick transitional (FA2) and/or shoreface (FA3-a) depositional environments (sections, and 4). This succession reveals a lake transgression onto subaerial alluvial fans or directly onto the Gombe Basalts (Fig. 9A). Above, the transitional (FA2) and shoreface $(F A 3-b)$ deposits indicate a subsequent shallowing trend attributed to a lake regression. The top of shoreface deposits in sections 3 and 4 marks the upper boundary of the sequence S1 (Fig. 4) and thus the lower boundary of S2 (SB2). The maximum flooding interval of sequence 1 (MFI1) is estimated in the offshore lacustrine deposits.

Overlying SB2, 10-15 m thick offshore lacustrine deposits (FA1) are observed in sections 3 and 4. Upward, they grade to either 1-3 m thick river-dominated nearshore (FA4; 
section 3), shoreface (FA3-a, section 4) or transitional deposits (FA2) characterized by shelly storm beds (section 5) and then, in sections 3, 4 and 5, to 10-15 m thick river deposits (FA5) (Figs. 4, 9B and C, 10A and B). Section 3, 4 and 5 show a rapid deepening of the lake above SB2 followed by the progressive shallowing and an emersion represented by river deposits. In sections 4, river deposits $(F A 5)$ are directly erosionally overlying a river mouth complex $(\mathrm{F} 4)$ and offshore deposits (FA1), infilling incised valleys (Fig. 10D and E). In section 5, river deposits show faint clinoforms that dip toward the central portion of the basin (Fig. 10A) revealing a progradational trend in this package. In sections 2,5 ?nd 6 , river sediments are topped by an erosional surface underlined by aligne $d$,ebbles, frequently coated by microbialites (Fig. 10C). Above this erosional surface $\lambda_{\mathrm{t}_{\mathrm{H}}}$ to $\mathrm{m}$-scale beach deposits $(F A 3-a)$ are observed in section 3 (Fig. 11A), overlain by 2 $30 \mathrm{~m}$ thick offshore deposits (FAl) marking the onset of S3 (Fig. 11B). In sectir $n_{\llcorner} 5$ ınd 6, offshore deposits directly overlay river deposits $(F A 5)$. In all sections, the $\_$np , boundary of river deposits $(F A 5)$ constitutes the top of S2 and, therewith, the sequence $\iota$ undary of sequence S3 (SB3). Located in more distal part, section 7 is mostly comno e $\downarrow$ of offshore material (FAl) occasionally intercalated by deposits from either transi nna (FA2) or nearshore (FA3) depositional environments. In section 7, two sequences and the onset of a third one are also delineated supporting interpretations in more ${ }_{\mathrm{r}} \mathrm{O}_{\mathrm{A} i \mathrm{imal}}$ domains.

Indeed, rirectly above SB3, 30-40 m of offshore mudstones (FA1) are observed (sections 6, 7 and 8; Fig. 11B). Upwards, offshore mudstones grade to m-scale sandstones and conglomerates deposited in river-dominated nearshore (FA4) environment, in places associated with storm deposits. Overlaying, river-dominated nearshore deposits progressively grade to a $90 \mathrm{~m}$ thick interval of river deposits $(F A 5-a)$, which show alternations of overbank deposits, alluvial channels that grade upward to alluvial fan deposits (Fig. 11C). For the same fluvial interval, Harris et al. (1988) report $160 \mathrm{~m}$, before reaching the Lomekwi Tuff. 
However, even if we did not observe such thickness on field, description by these authors reveals broadly similar river deposits all along the succession and as such, do not imply changes in our sequence delineation. Indeed, the progressive transition from offshore $(F A 1)$, to transitional (FA2), river-dominated nearshore (FA4) and then river (FA5) deposits reveal a general progradation. This sequence constitutes the regressive upper part of S3 (Fig. 4) and is topped by SB4. The MFI3 is estimated slightly below the Tulu Bor Tuff.

Alluvial plain deposits with a thickness of 35-40 m (section 9) directly overlie SB4. These sediments represent predominantly overbank deposit, 1 . arluvial plain environment (FA5-a; Fig. 11D) and they include the Lokalalei and K kisı lei Tuffs. In the upper part of section 9, two intervals of nearshore deposits (FA3- ${ }^{\prime}$ ) 11E). The second nearshore interval is supposed o cuincide with the 7-8 $\mathrm{m}$ thick basal nearshore interval observed in the lowerme ${ }^{\wedge}$ pal of section 10 (Fig. 4). In this section, nearshore deposits correspond to low-ent: y coastal swamp (FA3-b). Upwards, a $25 \mathrm{~m}$ thick package of alluvial plain deposits is $\mathrm{vc}^{-1}$ ain by a m-scale nearshore (FA3) interval grading upward to shoreface $(F A 3-a)$ and $\mathbf{u}^{` n}$ offshore mudstones $(F A 1)$. Offshore mudstones $(F A 1)$ are 40-45 m thick (Fig. 11F), in places intercalated by shoreface deposits $(F A 3-a)$. This succession forms the tran s. ${ }^{\circ}$ Ssive part of S4.

In section 12, about $20 \mathrm{~m}$-thick wave-dominated nearshore deposits (F3) are identified (Fig. 12A) above the offshore mudstones, evidencing a contraction of the lake (Nutz et al., 2017). This contraction started $\sim 15 \mathrm{~m}$ below, where the maximum flooding interval of $\mathrm{S} 4$ is estimated, and corresponds to the regressive part of S4.

Upward, nearshore deposits are overlain by transitional deposits (FA2) grading to offshore mudstones (FAl) marking the onset of a subsequent transgression attributed to S5 (Fig. 4). In section 13, the regressive part of S4 is not observed. Here, above the KBS tuff, 65 $\mathrm{m}$ thick of offshore mudstones (FAl) are present. They grade upward to $20 \mathrm{~m}$ thick 
transitional deposits (FA2) into which the Etir Tuff is identified. In the uppermost part of section 13, $15 \mathrm{~m}$-thick river-dominated nearshore (FA4) and shoreface (FA3-a) sediments are observed, which are correlated with the lowermost part of section 14. This succession records a shallowing attributed to the regressive part of S5.

Above SB6, $40 \mathrm{~m}$ of offshore mudstones (FA1), reveal a subsequent transgression attributed to the lower part of S6 (Fig.4). Hence, the top of shoreface deposits $(F A 3-a)$ at the bottom of section 14 is interpreted as the top of S5 and the lower limit of S6 (SB6), this longterm regressive trend of S5 marks a contraction of the lake $\mathrm{f}$ el "e another transgression that represents an expansion of the lake. Upward, offshore $c$ spo: its are overlain by a 50-60 m thick interval of river-deposits, commonly ember $u^{\prime}{ }^{\text {t y }}$ y shoreface $(F A 3-a)$ and riverdominated nearshore (FA4) intervals (Fig. 4). Overlying, ¿9 m thick offshore mudstones (FAl) evidence a subsequent transgression (Fig. $12^{\natural}, \iota_{\text {, }}$. The interval of river deposits reflects an emersion before another subsequent flo -ing. As such, this interval marks the regression associated with the upper part of S6 anc the transgression coeval with the lower part of S7 (i.e., SB7).

Sections 17 and 18, vich are located closer to the MRFL fault indicate that the offshore mudstones are cap sed by a $120 \mathrm{~m}$ thick interval that consists of alluvial plain deposits (FA5-b; Fig. 1 $2 \mathrm{D}, \mathrm{E}$ and F), in places intercalated by $\mathrm{m}$-scale river-dominated nearshore deposits (Fig. 12D, E). This interval corresponds to the regressive part of S7. Although our sections end $\sim 15 \mathrm{~m}$ above the Middle Nariokotome Tuff, at $\sim 1.25 \mathrm{Ma}$, data in Harris suggest an interval of river-derived deposits similar to FA5 embedded by common microbial constructions (oncolites) reflecting river-dominated nearshore deposits (FA4) until $\sim 0.75 \mathrm{Ma}$. According to Harris et al., (1998), progradation of such alluvial system remained limited with a shoreline that has fluctuated between 2 and $4 \mathrm{~km}$ far from the MRLF. 
The interval between $\sim 4$ and $\sim 3.44$ Ma includes the Lonyumun and Kataboi Members. This interval records two high-amplitude sequences (S1 and S2) and the lower part of a third high-amplitude sequence (S3) revealing two major T-R cycles and a subsequent Transgression (Fig. 13). The shoreline fluctuated from the MRLF to $\sim 8 \mathrm{~km}$ eastward. Lying directly onto the Gombe Basalts, the lowermost part of S1 is estimated at $\sim 4$ Ma. This time frame is further supported by the presence of the Moiti Tuff (3.97 Ma) in offshore mudstones (section 7), revealing that lacustrine conditions existed prior to this age. The top of S1 is not dated and no tuff is available to provide an absolute age. However, the regressive part of S2 is estimated around 3.6 Ma as revealed by the K82-742 and Loruth Tu' ${ }^{\prime}$ : tentified in section 3 (Table 2). Above, the transgression associated with S3 reached its $n_{1}$.ximum slightly after $3.44 \mathrm{Ma}$ (Fig. 4). In section 7, the presence of deposits (FA1, Ff 2 : nd FA3-b) that formed under water during the entire considered time interval sho $N_{s}$ th.t a lake continuously occupied the basin during this period even if fluctuations $\mathrm{cc}^{\mathrm{r}}$.red. From 3.44 Ma to 1.89 Ma, the Lomekwi, Lokalalei and Kalochoro Members recu-d the upper part of sequence S3 and the lower part of sequence S4 revealing a long-tarm $r$ igression followed by a subsequent transgression. Transition from the regressive renc of S3 to the transgressive trend of S4 is estimated to be slightly older than the Lokaıc ${ }^{1}{ }^{\text {e; }}$ Tuff (i.e., slightly older than $\sim 2.53 \mathrm{Ma}$ ) where alluvial plain deposits become predor-itiant. As such, the long-term regressive trend associated with S3 is estimated between $\sim 3.44$ and $\sim 2.53$ Ma while the long-term transgressive trend of S4 is estimated to start after 2.53 Ma. The maximum flooding interval of S4 (i.e., MFI4) is estimated $\sim 15 \mathrm{~m}$ below the KBS Tuff, marking the onset of the regressive part of S4 slightly before 1.89 Ma. Close to the border fault, 10 m-thick wave-dominated deposits (F3) embedded in river deposits reflect this maximum flooding interval (Fig. 11G). Superimposed, three higher-frequency sequences are observed during the long-term transgression of S4 (Figs. 4,13 ). From $\sim 1.87$ to $\sim 0.75 \mathrm{Ma}$, the Kaitio, Natoo and Nariokotome Members record the 
upper part of sequence S4 and 4 sequences referred to as S5, S6 and S7 (Fig. 4). Limits of sequences are particularly uncertain in this interval, however SB5 is estimated at $\sim 1.76$ (Nutz et al. 2017) while SB6 and SB7 are estimated slightly younger than $\sim 1.44 \mathrm{Ma}$ and between 1.43 and $\sim 1.4 \mathrm{Ma}$, respectively. The maximum flooding interval (i.e., MFI7) of S7 is estimated at $\sim 1.4 \mathrm{Ma}$ while the regressive part of S7 likely includes all the succession until $0.75 \mathrm{Ma}$, even if subordinate-order cycles might have occurred.

\subsection{Sedimentary systems}

Combining the interpretation of depositional environmer ts and their lateral relationships (Fig. 13), two sedimentary systems reconstructed in the We st Turkana area are presented and referred to as type-1 and type-2 (Fig. 14). Fa $\mathrm{h}$ sedimentary systems represents the coexistence of different depositional envi on nen s along an ideal downslope transect from the border fault to the central portion of the vasin. These sedimentary systems alternatively developed between 4.00 and $1.25 \mathrm{Na}$ ss sedimentation varied through time in the West Turkana area.

The type-1 sedimen $\cdot r$ system is characterized by the predominance of waveinfluenced coastal depo its. From the border fault to the central portion of the basin, the type1 sedimentary system consists of a few km-wide river deposits near the border fault. Where observed, river deposits form alluvial fans mostly made of fine conglomerate to gravelly sandstones indicating sheetflood-dominated alluvial fans $(F A 5-b)$, which are laterally associated with alluvial plain deposits $(F A 5-a)$ showing alternations of overbank deposits and channels. Alluvial fans are fed by rivers draining the western rift shoulder. Basinward, river systems grade rapidly to thick coastal wedges that consist of wave-dominated nearshore deposits (FA3) such as shoreface, beaches and washover fans that form wide strandplain. 
Finally, wave-dominated nearshore deposits connect laterally to storm-dominated transitional (FA2) and then to offshore deposits (FA1). The type-1 sedimentary system is characterized by (i) the limited development of alluvial fans along the border fault and (ii) the important development of wave-dominated coastal wedges. Type-1 sedimentary systems are conspicuously recognized between $\sim 4$ and $\sim 3.40$ Ma and between $\sim 2.5$ and $\sim 1.42 \mathrm{Ma}$ (Fig. 13).

In contrast, the type- 2 sedimentary system is charact cized by the predominance of river deposits. From the border fault to the central portion of he $\iota$ asin, type- 2 is characterized by wide conglomeratic alluvial fans which have been 'epe sited mostly by debris flows. Laterally, alluvial fans grade to an alluvial plain $\left(F^{1} 5-a\right)$ and then to river-dominated nearshore deposits (FA4). Toward the basin, these deposits rapidly grade to offshore mudstones (FA1). Finally, in opposition 'o type-1, type-2 sedimentary system are characterized by the development of (i) W1 ${ }^{\curvearrowright}$ and thick river deposits along the border fault in the form of alluvial fans and plains, 'ii) river-dominated nearshore deposits in more distal areas and (iii) a scarcity of $x$ ave dominated coastal wedges and features. The type-2 sedimentary system is observ $\sim$ '.uring periods between $\sim 3.40$ and $\sim 2.5 \mathrm{Ma}$ and after $\sim 1.42$ Ma (Fig. 13) in thick pa $\mathrm{ka}_{\varepsilon}$ es associated with regressive trends during periods of long-term progradation.

Fundamental differences between type-1 and -2 sedimentary systems derive from the competition between the development of wave-dominated coastal and river-dominated systems in West Turkana. Fluctuation in the amount of sediments entering the basin from the western rift shoulder likely controlled the shifts from one system to the other. Indeed, during periods of reduced sediment supply, alluvial systems were smaller and processes related to waves and alongshore drift were dominant forming successive prograding and retrograding strandplain systems at the origin of type-1 sedimentary system. Lake level fluctuations were 
the main mechanism to drive transgression-regression cycles revealing dynamics of an “accommodation-dominated system" (Neal and Abreu, 2009; Zhang et al., 2019). In contrast, during periods characterized by an important sediment supply, alluvial systems developed and prograded toward the basin forming quasi-continuous regressive intervals regardless paleolake fluctuations. The flux of sediments towards the basin inhibited the expression of wave-related processes, except perhaps during infrequent short and abrupt lake level rises. Hence, type-2 sedimentary system rather reveals dynamics associated with "supplydominated systems" (Burgess and Hovius, 1998; Carvajal and ₹teel, 2006; Zhang et al., 2019).

\subsection{Paleovegetation changes}

Both the Nachukui and the Shungura rer $\mathrm{dr}^{1} \mathrm{~s} \iota \mathrm{f}^{13} \mathrm{C}_{\text {pedogenic carbonate }}$ exhibit very widespread values (Fig. 15). Ranging from $-10 \%$ to $\%$ o these values indicate heterogeneity in the

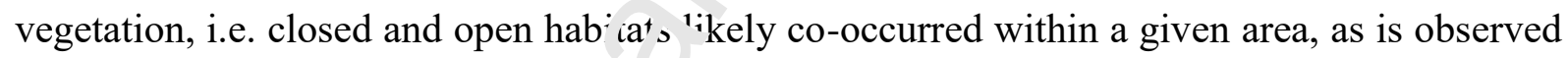
today for the riparian forest al $n_{1}$ ? the Omo River in an otherwise open savanna-dominated landscape. After data processit ${ }_{i}^{-}$marked trends emerge from the $\delta^{13} \mathrm{C}$ records (Fig. 15). The isotopic record of soi ${ }^{1}$ ca bon te from the Nachukui Fm shows an almost steady increase in $\mathrm{C}_{4}$ biomass, suggesting gre $\mathrm{d} \cdot \mathrm{al}$ aridification from $\sim 3.90 \mathrm{Ma}$ to $\sim 0.90 \mathrm{Ma}$ in West Turkana area. A significant biome change occurred at $\sim 3.25 \mathrm{Ma}$, when woodland/bushland/shrubland were replaced by wooded grassland, suggesting a change in water supply as woody cover dropped below $40 \%$. The woody cover at West Turkana reached its smallest extent at $\sim 2.00 \mathrm{Ma}$, and between $\sim 1.50$ and $\sim 1.30 \mathrm{Ma}$. In the Omo Valley, $\delta^{13} \mathrm{C}$ record of the the Shungura shows a different pattern. Interestingly, the Omo Valley exhibits a much longer record of woodland/shrubland/bushland than West Turkana, which lasted until $\sim 1.85$ Ma. Woody cover was always greater in the Omo Valley than in West Turkana until ca $1.85 \mathrm{Ma}$, suggesting 
greater water supply through rainfall, overbank floods or as groundwater in the Omo River alluvial plain. After 1.85 Ma, both records indicate wooded grassland with inferred woody cover not exceeding $20-40 \%$. Our results thus show that like West Turkana area, the Omo Valley underwent a long-term aridification between $\sim 3.20$ and $\sim 1.25 \mathrm{Ma}$. However, changes in the woody cover as inferred from changes in the $\delta^{13} \mathrm{C}$ records seem to have been more gradual in West Turkana than in the Omo Valley. In the Omo Valley, periods with maximum woody cover of about 50/60 \% occurred twice, in the lowermost part of the record at $\sim 3.20$ $\mathrm{Ma}$ and between $\sim 2.25-2.00 \mathrm{Ma}$ revealing particularly wat : onditions. Although less pronounced than later at $1.65 \mathrm{Ma}$, somewhat drier conditic $1 \mathrm{~s}$.eem to have reduced tree cover between $\sim 2.70$ and $\sim 2.50$ Ma.

\subsection{Forcing factors}

\subsubsection{Origin of lake-level fluctuation.}

Lake level fluctuations can be for -1 a sarious timescales by many factors, including climate, tectonism or volcanism (Tiercelin, 1990; Cohen, 2003). Changes in the precipitation/evaporation $r_{1}$ (c (.e., $\mathrm{P} / \mathrm{E}$ ratio) can drastically modify lake level, especially in systems with high clima: sensitivity such as the East African Rift System (Street-Perrott and Harrison, 1985; Trauth et al., 2010). Modifications of river catchments by tectonic events (i.e., block rotations, development of faulted barriers) can also modify the water balance of a lake. Furthermore, modifications of the basin physiography in active rift systems can also significantly modify lake levels at constant $\mathrm{P} / \mathrm{E}$ ratio. Such modifications may occur by variation in subsidence through time, either tectonically or by repeated subsidence pulses related to volcanism. Indeed, important volcanic events potentially lead to either adjustment of the crust after successive emptying of a magma chamber under the basin or isostatic 
adjustment caused by magma infill of significant proportions of the basin. Moreover, tectonism and volcanism can change significantly the position and threshold elevation levels of a lake outlet. In case of an overfilled lake configuration (sensu Carroll and Bohacs, 1999), the lake level is modified. Given the potentially intricate interactions among climate, tectonism and volcanism on lake levels through time, the respective contributions of these factors need to be reconstructed through time to understand the causes of high-amplitude fluctuations.

In the West Turkana area, evolution of the woody coven (N ? chukui $\delta^{13} \mathrm{C}$ record) does not match the reconstructed evolution of the paleolake Wa er-level (Fig. 15). Major lake highstands are not coeval with any remarkable neratı shifts in $\delta^{13} \mathrm{C}$ values nor any particular periods of greater woody cover. It is the efo unlikely that rivers activity in the West Turkana area and local paleohydrologic: $1 \iota^{\wedge n}$ ditions onto the western rift shoulder had any significant control on the paleolake flo ctuations. In opposition, evolution of the woody cover in the Omo Valley (Shungura $\delta^{2} r$ record) shows that major lake highstands between 3.2 and 1.25 Ma, namely part if :.e Lokochot, Lorenyang and Nachukui highstands established during periods of p.rticularly high woody cover (negative shifts of $\delta^{13} \mathrm{C}$ values),

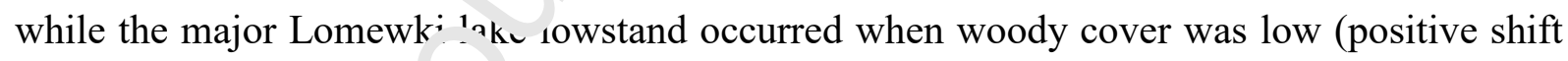
of $\delta^{13} \mathrm{C}$ values). Moreov r, the interval between 1.9 and $1.5 \mathrm{Ma}$ characterized by a general reduced extent of the paleolake, even water-level fluctuations occurred, is coeval with an interval of particularly lower woody cover (positive shit of $\delta^{13} \mathrm{C}$ values). Such a match between the reconstructed paleolake water level and woody cover in the Omo River floodplain strongly supports that the activity of the Omo River controlled major fluctuations of the paleolake. Indeed, greater woody cover in the Omo Valley can only be achieved with enhanced regional rainfall over the river catchment and the resulting augmentation of groundwater in bigger, larger, and shallower aquifers. We conclude that rainfalls over the 
Ethiopian Dome controlled high amplitude paleolake fluctuations at least between 3.2 and 1.25 Ma, and by extension all along the considered time interval due to a similar source configuration before and after that period. This is supported by the modern and recent configurations, as the Omo River provides $80-90 \%$ of water entering the modern Lake Turkana (Yuretich and Cerling, 1983; van der Lubbe et al., 2017), with a lower proportion that nevertheless exceeded 50\% (van der Lubbe et al., 2017) during the African Humid Period. Finally, by confronting reconstructed evolution of paleolake level and evolution of woody cover, we demonstrate that climate was the dominant $f_{a c l} \cdot$ that controlled the highamplitude paleolake fluctuations. Considering that superir.ıp sed higher-frequency paleolake fluctuations were also controlled by climate (Joordens $e_{\iota}$ ^l., 2011; Nutz and Schuster, 2016; Nutz et al., 2017), climate was the preponderant fact ${ }^{+}$or the origin of paleolake fluctuations during the Plio-Pleistocene.

\subsubsection{Origin of type-1 and type-2 sedime: ary systems in West Turkana}

The repeated alternations of type 1 and type-2 sedimentary systems (Fig. 14) in West Turkana mostly derived from changes $n$ the amount of sediment supplied to the basin from the western rift shoulder. In reas :d sediment supply from the western rift shoulder may have two potential origins: (i) cl $m$ ate, as increased rainfall increases the transport capacity of rivers, and thus influences the amount of sediment entering the basin or (ii) tectonic, as a pulse of the rift shoulder uplift and rejuvenation of the relief can enhance denudation and increase both size and amount of sediments transported by the rivers into the basin. The Nachukui $\delta^{13} \mathrm{C}$ record shows that during the two intervals of increasing sediment supply that led to the development of the type-2 sedimentary system (i.e., $\sim 3.40-2.50$ Ma and after $\sim 1.42 \mathrm{Ma}$ ), woody cover in West Turkana decreased (Fig. 15). Hence, the increased sediment supply observed in West Turkana between $\sim 3.40-2.50 \mathrm{Ma}$ and after $\sim 1.42 \mathrm{Ma}$ cannot be attributed to 
increased rainfall. Based on that, we attribute the most part of increased sediment supply to pulses of the rift shoulder uplift and the resulting increase of denudation. For the period between $\sim 3.40-2.50 \mathrm{Ma}$, which is coeval with an aridifiation, we cannot rule out a minor influence of the increased erosion deriving from the likely reduced vegetation onto the rift shoulder. However, this process is not invoked for increased sediment supply after $1.42 \mathrm{Ma}$, which is coeval with wetter conditions compared to the former configuration.

As a conclusion, type- 1 sedimentary system reflects a sedimentary system controlled by lacustrine processes responsible for the redistribution of clasi $\mathrm{s}$ associated with low to moderate sediment supply delivered by transverse rivers $r$ on. ing from a moderately-elevated rift shoulder. Paleolake fluctuations are expressed iv successive transgressions and regressions controlled by rainfall fluctuations over tr.e ${ }_{L^{+}}$thiopian Dome and the catchment of the Omo River. The modern western margin of the North Lake Basin in the Turkana Depression, which displays a remarka' 'e ,erie of strandplains, spits and wave-dominated delta evidencing massive reworking oi clastics by coastal waves and alongshore drift (Nutz and Schuster, 2016; Schuster and $\mathrm{Nu}>2018$ ), is a relevant analogue of type-1 sedimentary system (Fig. 14). In contrast, $:$ pe- 2 sedimentary system was mostly controlled by a pulsed uplift of the rift shoulder. Ex $\mathrm{E}^{\mathrm{s}}$ on of this newly-formed relief provided important sediment supply that led to a con : nuuus progradation even the probable fluctuations of the lake, likely except during particular short-term significant lake level rises. The modern western margin of the Chew Bahir basin (southern Ethiopia) bordered by well-developed alluvial fans fed by sediments coming from the Hamar Ranges is an accurate modern analogue of type-2 sedimentary systems (Fig. 14).

\section{INTERPRETATION AND DISCUSSION}




\subsection{Paleoenvironmental reconstructions - synthesis}

Using sedimentological sections, panorama interpretations, and compiled $\delta^{13} \mathrm{C}$ in soil carbonate datasets, we investigated paleoenvionmental changes in the West Turkana area. Seven key periods are represented reflecting different paleolandscapes (Fig. 16). Each period is characterized by specific sedimentary dynamics, lake level and woody cover reflecting various combinations of water and sediment supply from both the Western Turkana and the Omo Valley areas.

From $\sim 4.00$ to $\sim 3.60 \mathrm{M}$, a paleolake highstand referre $ı$ to is the Lonyumun Highstand established in the northern Turkana Depression (Fig. 16t.). I1. West Turkana, the lake shore reached the fault scarp and, at least locally, water inr ade ${ }^{\top}$ downstream parts of the valleys of the rift shoulder. Water was fresh (Cerling, 197n. Van Bocxlaer, 2020). Sedimentation was dominated by wave-related coastal proceseas, ${ }^{+}$vpe- 1 sedimentary system) mixing clastic and carbonate (mollusks) material. A low to mı terate amount of sediment was supplied from the moderately-elevated rift shoulder ar as th system was accommodation-dominated. Alluvial systems along the border fault v'ert noorly developed, and it is likely that little space was available between the lakesin re and the fault scarp to allow an extensive strandplain to develop even under pre valing wave-dominated processes. The woody cover is estimated around $55-60 \%$ indicating significant activity of rivers coming from the rift shoulder and thus that rainfall was important over the West Turkana relief.

Between $\sim 3.60-3.50 \mathrm{Ma}$, the lake level abruptly dropped causing a lake lowstand, i.e. the Lokochot Lowstand (Fig. 16B). Following the shoreline retreat, rivers entered the basin and reworked previously deposited sediments forming incised valleys. During this period, the area was non-depositional. This pronounced lake regression occurred while the woody cover in West Turkana was high, around 50\%, suggesting that rainfall in this area and/or over the Lappur Range at that time did not decrease majorly. It is possible that the short-term lake 
level drop reveals an abrupt reduction of rainfall in the catchment of the Omo River, but as no data on woody cover from the Omo Valley around $\sim 3.50 \mathrm{Ma}$ are available, the issue cannot be verified. After $\sim 3.50 \mathrm{Ma}$, a lacustrine transgression occurred that reflects the progressive establishment of the Lokochot Highstand, which reached its largest extent slightly before 3.44 Ma. The water was fresh to slightly brackish (Cerling, 1979). Yet, with a woody cover of $45 \%$, this period was still particularly humid in West Turkana.

From $\sim 3.40$ to $\sim 2.60 \mathrm{Ma}$, the paleolake experienced a progressive regression associated with a change of sedimentation mode (Fig. 16C and $\mathrm{n}$ ). The sedimentation became primarily controlled by river deposits and a supply-dom «a `a system developed resulting from the increased elevation of the rift shoulder favorite the intensification of erosion and thus of the sediment production. As such, the sedim 2 เ supply from rivers that drain the rift shoulder drastically increased. A belt of allu $i_{a}{ }^{*}$ stems developed along the border fault (Fig. 16C), and progressively progradec ${ }^{\circ}$ vard the central portion of the basin pushing the shoreline basinward regardless lake-le v $\mathrm{l}$ fluctuations, likely except during occasional shortterm and particularly important phase. $r_{i}$ lake level rises. Coeval to the progressive fall of the lake level, woody cover decre a ed $\mathrm{n}$ West Turkana (from 45 to $35 \%$ between 3.40 and 2.60 $\mathrm{Ma}$ ) and in the Omo River $\mathrm{c}^{{ }^{+}{ }^{+1}}$ ment (from 65 to $45 \%$ between 3.20 and $2.60 \mathrm{Ma}$ ) revealing significant rainfall decı 'ass in both areas. This period is also characterized by an important diminution of $\delta \mathrm{A}$ favoring faster progradation. Altogether, alluvial belt progradation, lake level fall and reduced rate at which ccommodation space is created led to a drastic retreat of the shoreline, likely as important as during the Lokochot Lowstand. The paleolake reached its lowest extent at around $2.60 \mathrm{Ma}$, which marks the peak of the Tulu Bor Lowstand. At that time, a $>8$ kilometers wide river-dominated system (Fig. 16D) characterized the Western Turkana area. 
From $\sim 2.60$ to $\sim 2.10 \mathrm{Ma}$, despite minor water-level fluctuations, the paleolake progressively extended. The mode of sedimentation changed with a progressive shift from river deposits (type-1 sedimentary system) to wave-dominated deposits (type-2 sedimentary system). This change suggests that the pulse of rift shoulder uplift became interrupted and the intensity of relief erosion progressively became less intense. At the same time, woody cover in the Omo Valley increased largely (from $45 \%$ to $65 \%$ ), although it continued to decrease in the West Turkana area (from $35 \%$ to $25 \%$ ). Hence, whereas conditions in the catchment of the Omo River humidified, the ongoing aridification continued in Wt.+ Turkana. Between $\sim 2.10$ and $\sim 1.90 \mathrm{Ma}$, the paleolake reached a maximum ext $\mathrm{xt}_{\mathrm{t}}$ referred to as the Lorenyang Highstand (Fig. 16E). Sedimentation is wave-dominatec with mixed clastic and carbonate (mollusk shells) material. A limited amount of sedirne. + was supplied from the moderatelyelevated rift shoulder and alluvial systems alor g ie jorder fault were poorly developed.

From $\sim 1.90$ to $\sim 1.85 \mathrm{Ma}$, the ral olake shrank until it reached a lake lowstand between $\sim 1.85$ and $\sim 1.75$ Ma (Fig. $16 F$ ). Sedimentation was almost exclusively wavecontrolled, with carbonate-dominntec r.taterials (mollusk shells) and more limited clastics. Water became more brackish i Cerıng, 1979). Alluvial systems along the border fault were very poorly developed as a $v$ rr low amount of sediment was supplied from the moderatelyelevated rift shoulder. This regression was accompanied by a drastic decrease of the woody cover in the Omo Valley (from 60 to 35\%). In the West Turkana area, however, woody cover increased slightly (from $25 \%$ to $30 \%$ ) (Fig. 15). This marks a transition to drier conditions onto the Ethiopian Dome and slightly wetter conditions in the West Turkana area. From 1.75 to $1.45 \mathrm{Ma}$, the paleolake experienced two limited expansions separated by two contractions, while the woody cover in both the West Turkana and the Omo Valley areas ranges between 30 and $35 \%$. Hence, although some fluctuations occurred, reduced rainfall over the Ethiopian Dome substantially constrained the extent of the paleolake. 
Around $\sim 1.40 \mathrm{Ma}$, the paleolake reached another significant lake highstand referred to as the Nachukui Highstand. Water was brackish (Cerling, 1979). This highstand is coeval with greater woody cover and, hence, rainfall in the Omo River catchment area, but drier conditions in West Turkana. Slightly before 1.40 Ma, the mode of sedimentation changed and became river-dominated with abundant clastics associated with recurrent microbial oncolites and stromatolites. An alluvial belt developed along the border fault and progressively prograded toward the central portion of the basin. Comparably to the period between $\sim 3.40$ and $\sim 2.50 \mathrm{Ma}$, at $\sim 1.40 \mathrm{Ma}$, a new pulse of the rift shoulder urlift $\mathrm{s}$ d to increased erosion and a supply-dominated river system was established (Fig. 'oc'. However, as opposed to the $\sim 3.40-2.50$ Ma period, the increasing $\delta \mathrm{A}$ (up to $4251 \mathrm{~s} . \mathrm{Ma}^{-1}$ ) around $\sim 1.40$ Ma probably inhibited extensive lateral progradation and major st or 'ine migration into the basin. Rather, it favored aggradation, which is confirmed $b_{/} \therefore$ e coastal river deposits embedded in river deposits observed close to the border $f_{\mathrm{fl}}, \mathrm{c}$ around $\sim 1.25 \mathrm{Ma}$, showing limited shoreline migration between $\sim 1.40$ and $\sim 1.25$ เง.า. According to Nariokotome Member architectures reported by Harris et al., (1988), this ' $.1 \mathrm{~g}$-term progradation appears to have continued until $\sim 0.75 \mathrm{Ma}$, even if occasional si: rrt-lerm transgression occurred.

\subsection{Paleoclimate impı atıons}

Precipitations over the Turkana Depression and the Ethiopian Dome are controlled by the annual latitudinal migration of the Intertropical Convergence Zone (ITCZ) between $15^{\circ}$ north and $15^{\circ}$ south, seasonally delivering moisture from both the Indian Ocean and the Atlantic Ocean (Levin et al., 2009; Nicholson, 2017). Precipitations, however, drastically differ in the Turkana Depression and the Ethiopian Dome, and this difference is attributed to local factors (Nicholson, 2017) such as (i) the relief, south-west of the Turkana Depression, which is supposed to limit the flow of moist air from the Congo Basin and to create lee rain shadows 
(Nicholson, 2016), and (ii) the recurrent Turkana jet, which significantly modulates precipitation in the Turkana Depression (Nicholson, 2016, 2017). Hence, whereas precipitation in the Turkana Depression reflects local patterns, precipitation over the Ethiopian Dome may directly respond to larger-scale and global climate processes. Our study shows that changes in the water-level of the paleolake are closely associated with changes in the Omo Valley woody cover, which are indirectly related to precipitation changes over the Ethiopian Highlands. Thus, the paleolake appears to have responded to regional and global climate processes and thus represents a valuable archive for the Pin-Pleistocene paleoclimate in the horn of Africa.

Numerous studies demonstrate that variations of I. $^{-}$'solation constituted major controls on fluctuations of lake levels during the Plio-Ple:sh -ene in East Africa. By modifying intensity of rainfall, precession cycles have co $1 t_{\Perp}, 11 \_\mathrm{d}$ well-preserved lake fluctuations during the Plio-Pleistocene period (Deino et .' ', -006; Ashley, 2007; Nutz et al., 2017) and the Holocene (Larrasoana et al., 2013; S: 'nnahan et al., 2015). Increase of insolation due to changes in precession parameterc $1^{a r}$ odically led to increased intensity of monsoonal precipitation. Other studies (Trauıh et al., 2005, 2007) suggest that evolution of the eccentricity also is an imporm nt factor that impacted climate by modulating precession cycles. During periods of ecct trıuty minima, the amplitude of insolation peaks is lower and, as a result, the intensity and migration of the summer monsoon front is supposed to be drastically reduced over periods of 100 to $400 \mathrm{kyr}$. Thus, during periods of 100 to $400 \mathrm{kyr}$ low eccentricity, impact of precession is reduced and does not allow significant humid periods to establish. Precession cycles generated paleolake level fluctuations of a few tens of meters during the Plio-Pleistocene in the Turkana Depression (Nutz et al., 2017). However, the systematic impact of eccentricity is still debated. Boës et al., (2018) propose that eccentricity is a potential parameter at the origin of paleloake fluctuations, but this study concerns a 
limited time interval only. By confronting reconstructed fluctuations of the paleolake and the evolution of eccentricity between 4.00 and 0.75 Ma (Fig. 15), only a partial correlation appears to exist between long-term lake highstand or lowstand and particular periods of 100 to $400 \mathrm{kyr}$ eccentricity maxima and minima. Indeed, correlations between periods of loweccentricity and lake lowstands or high-eccentricity and lake highstands are not systematically observed. The humid period between 4.00 and 3.60 Ma is characterized by high eccentricity, which could suggest a direct control by insolation. However, between 3.20 and $2.90 \mathrm{Ma}, 2.40$ and 2.10 Ma or 1.90 and 1.70 Ma, similar high eccentricity patter.s do not coincide with the establishment of lake highstands. Conversely, although $t^{1} \mathrm{e}$ i w eccentricity period between 2.90 and 2.40 Ma is coeval with dry conditions, perinds hetween 3.40 and $3.20 \mathrm{Ma}$ or 2.10 and 1.90 Ma show relative low eccentricity and relat've nigh lake levels. A direct influence of eccentricity on precipitation is thus not syst $m_{1}$ ir slly observed and it is likely that direct insolation mostly modulated the climate of pre-established wet and dry periods derived from particular global climate events or trans.tions.

Between $\sim 4.00$ and $\sim 3.40 \mathrm{Ma}$, a global humid period supposedly affected East Africa. This humid period is associate . wilı the latest time of the "lower Pliocene forest expansion" period described by Bonne . $^{-1}$ e (2010), which constituted a global humid period in Africa between $\sim 6$ and $\sim 3.6$ Mi. win a climax centred at $\sim 4$ Ma. According to Bonnefille (2010), this climax of humidity may have originated from the closure of the Isthmus of Panama between 4.70 and 4.20 Ma (Haug, 1998) that led to major changes in Pacific and Atlantic waters organization and to a southwards shift of the ITCZ (Billups et al., 1999). However, more recent literature questions this explanation (Montes et al., 2015) proposing that the Isthmus of Panama may have closed much earlier, about 15 Myr ago. Following the humid period, the regression of the paleolake between 3.40 and 2.60 Ma coincides with a progressive transition to a dry and cool period onto the Ethiopian Dome, estimated between 2.70 and 2.50 Ma by 
Bonnefille (1983) and supported at continental-scale by reconstructions of Grant et al. (2017)

(Fig. 15). Two origins are proposed for this dry and cool period, the first is the direct impact in tropics of eccentricity-driven insolation changes following the mechanisms mentioned above (Trauth et al., 2009); the second is the onset of the Northern Hemisphere Glaciation (deMenocal, 2004), which is coeval with aridification in some places in the tropics (Bonnefille, 1983; Bobe et al., 2002). Although we cannot resolve this issue, we suggest that according to the intensity of this phase of aridification, a combined effect of both factors could be envisioned. Subsequently, the Lorenyang Highstand rovea's newly established wetter conditions onto the Ethiopian Dome with a climax from $\sim \sim 1$ to $\sim 1.90 \mathrm{Ma}$. The origin of this newly identified humid period on the Ethiopian Dome is unknown although coeval loweccentricity argues against an influence of direct ins sla 'on-driven increases of precipitation. The end of this humid period and the transitic n ' r rier conditions onto the Ethiopian Dome after $\sim 1.90$ Ma coincides with the est. $h l j$,nment of a stronger Pacific Walker circulation (Ravelo et al., 2004) which has been p.'nposed to have led to drier climate in Africa between $\sim 1.90$ to $\sim 1.50 \mathrm{Ma}$ (Trauth et al.. $\supset$ ( (). Finally, at around $1.40 \mathrm{Ma}$, a new important humid period reflects renewed wetter 'onaitions. Although the global origin of such humid period is not identified, it coincides $v$ it $^{1} \wedge$ a period of relatively high eccentricity which could have favoured a regional 'unndification. By the end, climate processes that influenced precipitations onto the Ethiopian Highlands, and thus fluctuations of the paleolake in the Turkana Depression, derive from the combination of global climate events modulated by the direct impact of insolation through the interaction of precession and eccentricity cycles.

\subsection{Did a single long-lived lake occupy the Turkana Depression between 4 and 0.75 Ma?}

Early paleoenvironmental studies (Cerling, 1979; Williamson 1981) proposed that the Turkana Depression has been occupied from $\sim 4.00$ to $\sim 0.75$ Ma by a single long-lived lake, 
but this paleoenvironmental reconstruction was later adjusted(Brown and Feibel, 1988, 1991). The latter authors suggested that sedimentation during this period was for $85 \%$ of the time river-dominated, occasionally interspersed by five paleolakes of variable extension and duration. These paleolakes have been further described by Feibel (1997) from old to younger as paleolakes Lonyumun, Lokochot, Lokeridede, Lorenyang and Silbo (Fig. 15). Whether a single, continuous long-lived lake or several shorter-lived lakes occupied the Turkana Depression is of particular paleoenvironmental relevance, among others to characterize water resources for aquatic and terrestrial biota, including hominine to 'nderstand the role of the various causal factors of environmental change, and to $x_{r}{ }^{1}$ an biogeographical dynamics, including both intra- and inter-basinal dispersal. The here : aported sedimentological data (Fig. 13) reveal that continuous lacustrine conditions occur d in the North Lake Basin between $\sim 4.00$ and $\sim 3.30 \mathrm{Ma}$ and between $\sim 2.30$ and $\sim$ ? Ma, even if lake extent varied through time. The repeated occurrence of mic $\cdot b^{j}$ dl constructions in strata of the Nachukui Fm between $\sim 1.25$ and $\sim 0.75 \mathrm{Ma}$ (Har:s et al., 1988) also supports recurrent lacustrine conditions in the area during that ner. $r$. Our data and interpretations hence suggest that the basin, was occupied by a sev al tuns of km-wide lake during at least $\sim 70 \%$ of the period between $\sim 4.00$ and $\sim 0.75:{ }^{3}$. No direct evidence of lacustrine conditions is identified between $\sim 3.30 \mathrm{Ma}$ ana $\sim . .0 \mathrm{Ma}$, which does not automatically imply the absence of a lake, however. Major incised valleys and canyons, which traditionally result from an important base level fall (Posamentier, 2001), are absent in this interval. This absence may support the existence of a lake although subaqueous offshore deposits are not observed in the available exposures. Hence, we are inclined to consider possible the view of a single long-lived large lake in the northern Turkana Depression between $\sim 4.00$ and $\sim 0.75 \mathrm{Ma}$, even if this lake experienced important fluctuations and periods of particularly reduced spatial extent during, as examples, the climaxes of both the Lokochot $(\sim 3.60$ to $\sim 3.50 \mathrm{Ma})$ and Tulu Bor lake 
lowstands $(\sim 2.70$ to $\sim 2.50 \mathrm{Ma})$. At that two periods, it is critical to estimate extent of paleolake Turkana along the North-South axis and some portions were possibly dry. Comparisons with previous studies reveal that three of the five palaeolake phases reconstructed by Brown and Feibel (1988, 1991), namely the Lonyumun, Lokochot and Lorenyang "paleolakes", coincide broadly with major highstands in our reconstruction. Exceptions concern the Lokeridede and Silbo phases. The Lokiredede paleolake is centred at $\sim 2.50 \mathrm{Ma}$ and considered to be brief (Feibel, 1997). Even if we did not observed deposits of this paleolake "phase", based on our results we suspect that it cor-esponds to a subordinateorder short-term transgression during the general Lor.te'v1 Lowstand, comforting the presence of a lake during this important lake lowstand ( c ncerning the Silbo paleolake, which is centred around $1 \mathrm{Ma}$, we attribute this lake phase in the wake of the Nachukui Highstand centred at $\sim 1.40 \mathrm{Ma}$, possibly representing a si jordinate-order short-term transgression during the general regressive trend. Hc ver er, our reconstruction differs from the previous ones by Brown and Feibel $(1988,1991$, and Feibel $(1988,1997,2011)$ mainly in the lowstand phases. These authors consideren lo w and phases to be characterized by the absence of lacustrine conditions in the $\mathrm{b}_{\mathrm{i}}$ sin, whereas we interpreted basinward sections to regularly contain lacustrine deposits. a'he that the spatial extent of aquatic environments was strongly reduced during these $\mu^{\prime}$ 'asus. In conclusion, a (quasi) long-lived, i.e., proto-lake Turkana, may have persisted during most of the Plio-Pleistocene in the Turkana Depression. It likely constituted an aridity refugium for terrestrial fauna, including hominins, as previously suggested by Joordens et al., (2011), in contrast with some other lakes of the East African Rift. This long-lived lake may have limited east-west terrestrial connections for most of the time, and dampened speciation and radiation between western and eastern rift sides, in turn favoring north-south connections. 


\subsection{Paleohydrography and aquatic community change}

How aquatic environments in the Turkana Depression were connected to those in other ecoregions over time has important implications on aquatic biota and faunal turnover. Although much is still unresolved, especially as to the drivers of faunal turnover, we provide preliminary considerations on historical biogeography.

During the Lonyumun Highstand ( 4.00-3.60 Ma), lacustrine environments covered most of the Turkana Depression. The paleolake was fresh and open, with an outflow to the Indian Ocean that drained the depression in the southeast (Cerling, 14:9; Brown and Feibel, 1988; Bruhn et al., 2011). The period coincided with persistent hun id conditions in West Turkana, evidenced by an extensive woody cover, and the river, ¿scilarging to the Turkana Depression likely ensured overall good hydrographic connectivicy, buth upstream and downstream of the paleolake. The mollusks that colonized th Iurkana Depression during the Lonyumun Highstand support widespread faunal ex $\iota^{\mathbf{1}}$ ange with other regions in Tanzania, Kenya and Uganda, which were inhabited by linea $e^{-e s}$ ancestral to the current Nilotic fauna (e.g. Van Bocxlaer et al., 2008; Van Bocy iar _011; Schultheiß et al., 2014; Ortiz-Sepulveda et al., 2020). Some fish taxa, e.g. S`mı:kiichthys, also support widespread faunal exchange within a

Nile-linked system (Stev a ${ }^{+}$¿v03) suggesting important rivers activity in the catchment of the paleolake and a hydru zraphic connectivity with both Nile-linked and central African river systems.

After the comparatively short-lived Lokochot Lowstand, during which the lake was endorheic, water levels rose to bring on the Lokochot Highstand ( 3.50-3.30 Ma). During this highstand the outflow towards the Indian Ocean was likely re-established to conditions during the Lonyumun Highstand (Bruhn et al., 2011), although the paleolake was slightly less extensive. A rainforest expansion towards the Turkana Depression was claimed by Williamson (1985) for this timeframe based on remains of the central African rainforest tree Antrocaryon 
from sediments of the Usno Fm in the Omo Valley. This fossil evidence suggests substantial renewed river activity in the catchment of the paleolake and hydrographic connectivity with central African river systems. In terms of aquatic communities, information is more limited. Williamson (1985) also reported that the freshwater gastropod Potadoma, which is currently restricted to central and West African rainforest steams (Brown, 1994), appeared simultaneously with Anthrocaryon in the Turkana Depression. However, the geochemical correlation for this interpretation has been refuted (Van Bocxlaer et al., 2008), and given that freshwater biota for the Lokochot Highstand remain poorlv do 'Imented, further work is required to infer precise hydrographic connectivity and fav atı atınities at that time.

After the Lokochot Highstand, a long-term prog. assive regression occurred ( 3.302.70 Ma), marking a period of negative water budgetse en if unfrequent second-order shortterm transgressions likely occurred during th $e^{n}{ }^{n}$ ral regression. As a result, aquatic biota and ecosystems in the Turkana Basin wc $\bullet$, s sverely disrupted, but how exactly this disruption occurred and at which time exactly is c.rrently unclear. Around 2.70-2.50 Ma, a colonization by a new assemblage of freshwater m.11 usks known as the Suregei Isolate fauna (Williamson, 1981; Van Bocxlaer et al., 2in8) uccurred coeval with a brief lake level rise during the Lomekwi Lowstand, i.e. 'the I rkeridede paleolake phase' sensu Feibel (1997). The invading taxa are known from issii deposits elsewhere in Africa, notably from the Albertine Basin (Van Damme and Pickford, 1999, 2003, 2010; Van Bocxlaer et al., 2008). Fossil evidence also suggests the invasion by freshwater sponges of the genus Potamophloios (Van Bocxlaer et al., 2008), which at present only occurs in the Congo Basin and Zambia (Manconi and Pronzato, 2002). Hence, all evidence indicates that some rivers that drain into the Turkana Depression became hydrographically connected to regions more to the southwest, i.e. the Congo River catchment. Modifications of river catchments that fed the Turkana Depression further south, such as that of the Turkwel and/or Kerio River, have perhaps caused such faunal exchange. 
The Suregei Isolate fauna disappeared from the Turkana Depression before the subsequent high lake level phase, the Lorenyang Highstand, which started 2.10 Ma ago.

During the Lorenyang Highstand, the paleolake was open, with an outflow to the Mediterranean Sea according to Bruhn et al. (2011). The period directly associated to the Lorenyang Highstand marks the arrival of a new assemblage of freshwater biota, which persists up to $\sim 1.40 \mathrm{Ma}$ in the Turkana Depression, suggesting that it persisted during the Kaitio, the Natoo 1 and 2 Lowstands. This fauna contains endemic mollusks (Williamson, 1981; Van Bocxlaer et al., 2008; Van Bocxlaer and Van Damme, ¿n09; Van Bocxlaer, 2011), which are marked by evolutionary change, and the fre',lv ter stingray Dasyatis (Feibel, 1993). The mollusks associated with this phase differ fron the previously mentioned Suregei Isolate fauna, implying that an ecological calamity $r$ au ${ }^{-d}$ extinction prior to recolonization. This phase of recolonization reflects the $h_{\_} \mathrm{dr}$,graphic reconnection of the Turkana Depression with surrounding drainage $s$, te $\wedge$. Given the indicated humidification in the Omo River catchment and simultaneous arlc: fication at West Turkana, aquatic mollusks likely reinvaded the paleolake via hydrogrənhi - econnections north of the Turkana Depression.

The final wave of frest ' vateı faunal invasion recorded in the Omo Group is known as the Guomde Isolate (Willianı 'r 1981; Van Bocxlaer et al., 2008), occurred at $1.10 \mathrm{Ma}$. This fauna has been recover ${ }^{1} 11$ the Koobi Fora, Nachukui, and Shungura Fms between $\sim 1.10$ and 0.75 Ma. The diversity of this fauna is lower than of that associated with the Lorenyang Highstand, but taxa sensitive to oxygen depletion and elevated water conductivity are present, suggesting a substantial period of stable conditions for freshwater life, and some morphological changes over time are observed in the fauna (Van Bocxlaer, 2011). This reveals that freshwater conditions were eventually re-established, although water was considered brackish during the Nachukui Highstand, at $\sim 1.40$ Ma (Cerling, 1979). The hydrographic 
connections that have led to this invasion were probably similar in nature to those that enabled faunal dispersal during the Lorenyang Highstand, but they were probably less elaborate.

In conclusion, even though lacustrine conditions persisted for long periods in the northern Turkana Basin between $\sim 4.00$ and $0.75 \mathrm{Ma}$, the aquatic fauna of the northern Turkana Depression records multiple events of complete faunal turnover, notably, but not exclusively in freshwater mollusks (Van Bocxlaer et al., 2008). Further investigations are required to understand (1) how these ecological calamities were brought on if not by desiccation; (2) to what extent aquatic and terrestrial taxa wt. similarly or differently affected by these calamities, and (3) how the Turkana $\boldsymbol{L}$, yression was hydrographically connected to other catchments in the East African Rift nve - time.

\subsection{What was the impact of tectonism and olcanism on paleolake fluctuations?}

Drivers of water level fluctuations in the Furkana Depression have been another matter of debate for decades. Some authors pr'p seci that major lacustrine highstand in this basin derive from regional or global climate con ditions (Trauth et al., 2005, 2007; Maslin and Trauth, 2009; Maslin et al., 2014). Oi ars (Feibel, 1988; Brown and Feibel, 1991; Bruhn et al., 2011; Lupien et al., 2018; Bois eı al., 2018) rather propose that palaeolake level fluctuations are primarily controlled by lc sal tectonic or volcanic events, with a minor overprint of global to regional climate patterns. An emblematic example used to support this latter statement is the Lorenyang lake phase (i.e., highstand centred at $\sim 2.10-1.90 \mathrm{Ma}$ ) which is attributed to the Lenderit Basalts flooding volcanic event that would have blocked the lake outlet of the protolake Turkana (Bruhn et al., 2011), raising lake level as a consequence. Here, we demonstrate that the Lorenyang Highstand coincides with the largest negative shift in $\delta^{13} \mathrm{C}$ isotopic values in the Omo Valley, revealing a coeval major increase of precipitation on the Ethiopian Highlands. Hence, whether or not volcanism have raised the paleolake outlet and 
consequently increased the maximum potential available space to be filled by water, expansion of Lake Lorenyang and infilling by water of the newly-formed available space resulted from increased volume of water entering the basin due to wetter conditions onto the Ethiopian Dome. As such, the Lorenyang Highstand has been climatically-induced. Similarly, we reveal that the other high-amplitude paleolake fluctuations between $\sim 4.00$ and $\sim 0.75 \mathrm{Ma}$ were controlled by climate, as major lake highstands are associated with increased precipitations onto the Ethiopian Dome. Finally, we propose that tectonism and volcanisms had only a minor influence on proto-lake Turkana fluctuations

\section{CONCLUSION}

Combining reconstructions of sedimentary dỵ $\mathfrak{q}^{r} \wedge \mathrm{i} \mathrm{s}$, paleolandscapes and paleovegetation, we provide an updated synoptic review of Jaleuenvironmental change in the West Turkana area, between $\sim 4.00$ and $\sim 0.75 \mathrm{Ma}$. G.r main conclusions are:

- Facies and sequ $\mathrm{Act}$ `nalyses reveal that proto-lake Turkana experienced seven high-amplitude traı gre ssion-regression (T-R) cycles between $\sim 4.00$ and $\sim 0.75$ Ma;which are $\eta^{1} i^{10}$ es, superimposed by lower amplitude T-R cycles. Four major lake highstands are recognized and referred to as Lonyumum $(\sim 4.00-3.60 \mathrm{Ma})$, Lokochot ( 3.50-3.40 Ma), Lorenyang ( 2.10-1.90 Ma) and Nachukui $(\sim 1.40 \mathrm{Ma})$ during which proto-lake Turkana may have outflowed first toward the Indian Ocean and after $\sim 2.20 / 2.00$ Ma toward the Mediterranean Sea. These four major lake highstands are associated with two shorter-duration and less extensive lake highstands referred to as Katio $(\sim 1.75-1.50 \mathrm{Ma})$ and Natoo $(\sim 1.44-1.43 \mathrm{Ma})$. In between lake highstands, successive major lake lowstands occurred during which proto-lake Turkana was endoreic. An important short-term lake lowstand referred to as the 
Lokochot Lowstand $(\sim 3.60-3.50 \mathrm{Ma})$ is identified at the end of the Lonyumun Highstand. The long-term Lomekwi Lowstand reaches a minimum between $\sim 2.70$ and 2.50 Ma while three shorter-term lake lowstands referred to as Kaitio, Natoo 1 and Natoo 2 characterize the period between $\sim 1.90$ and $\sim 1.45 \mathrm{Ma}$.

- The $\delta^{13} \mathrm{C}$ values in soil carbonates allowed us to compare changes in sedimentation and the woody cover in both the West Turkana and the Omo Valley areas. This comparison reveals that the evolution of rainfall over the Ethiopian Dome and the drainage basin of the Omo River controlled high amplitude fluctuations of proto-lake Turkana during the Plio-Pleistocene per va. In contrast, rainfall fluctuations over the West Turkana area did not significan ${ }^{+1} \mathrm{y}$ in fluence proto-lake Turkana waterlevel. Moreover, our study demonstrates that $\left.{ }^{+} \mathrm{ra}_{\imath}\right\urcorner$ fall evolution differed continuously between the two areas and suggests th at "Nfst Turkana climate is strongly influenced by local effects. Our results $t_{1}$ 's suggest that terrestrial faunas occupying West Turkana may have experiencea significantly different climate conditions than those elsewhere in the Turkana $\Gamma \curvearrowright$ pr $`$ sion.

- Sedimentary dy ${ }^{{ }}$mics in West Turkana show alternations between river- or wave-dominated lake $r$ argins over time. These changes are attributed to important variation in the ${ }^{\text {rdiment }}$ supply coming from the western rift shoulder that led to the alternations between typical "accommodation-" and "supply-"dominated systems through time. Pulses of activity of the western border fault (i.e., MRLF) repeatedly formed high relief, which caused repeated periods of increased denudation and sediment supplied to the basin. These high-relief periods are estimated to have occurred between $\sim 3.4$ and $\sim 2.5$ and after $\sim 1.42 \mathrm{Ma}$.

- Climate processes that influenced Ethiopian Highlands, and significantly influenced the high-amplitude fluctuations of proto-lake Turkana likely derive from 
the interaction of global climate events and the direct impact of insolation through precession cycles modulated by eccentricity variations.

- Whereas the reconstructed lacustrine highstands overall coincide well with previously recognized paleolake phases (Brown and Feibel, 1988, 1991, Feibel 1997, 2011), our reconstruction differs substantially during lake lowstands. Whereas these phases were previously reconstructed to have been river-dominated, our sediment analyses suggest that lacustrine conditions occurred for at least $70 \%$ of the time. Considering all evidence, we interpret longer-lasting lolre phases and potentially even a single, continuous paleolake between 4.00 and U.75 Ma. Aquatic faunas display several major turnover events indicating that sever - ecosystem calamities nevertheless occurred. Further studies are required to unr ars and the underlying causes, and how faunal and environmental changes are $\ln _{\iota} n_{\text {. }}$ in the Turkana Depression.

- $\quad$ Finally, our study sugge ${ }^{+} \mathrm{s}$ that tectonism, volcanism and climate interacted in intricate ways. Tectonism,$n \perp$ volcanism have had an important effect on sedimentation modes; : owever, their impact on high-amplitude proto-lake Turkana water fluctuations $a_{n}{ }^{1}$ tr.e establishment of the successive major lake highstands and lowstands appe $\cdot \mathrm{s}$ : $\mathrm{u}$ have been limited.

Since the paper by Harris et al., (1988), this contribution is the first to present a synthetic investigation of the Nachukui Fm. Our study shows that such comprehensive studies can provide a basis for robust large-scale paleoenvironmental reconstructions and information on paleolake fluctuations, which complement detailed site by site examinations. We propose that similar approaches could be developed on other Plio-Pleistocene deposits, especially, but not exclusively, for other geographically extensive formations with hominin sites. Finally, the 
next step is to routinely integrate this approach in workflows adopted by paleontological and archeological research programss.

The following are the supplementary data related to this article.

Table S1. Geographic coordinates of measured sections.

\section{ACKNOWLEDGEMENTS}

This work is a contribution to the Rift Lake Sedimentology proj ${ }^{\text {cet }}$ (RiLakS) funded to MS and AN by the Total Oil Company between 2014 and 2016. T'is work benefited from the ANR HADOC (Human Ancestors Dispersal: the role $f$ Cl1mate) project; (ANR-17-CE310010-02) led by DB and from the 80PRIME CNRS p pi ct (EnviroMolSed) led by BVB. We thank the Kenyan guides, Francis Emekwi and $S_{\lrcorner n}$ my Lokorodi who worked with us in the field. This research project was conducte $\lrcorner$ in parnership with the National Oil Corporation of Kenya. We specifically thank Georgc Muia, Kivuti Nyagah, Sumayya Hassan-Athmani, and Ambrose Ofafa. Permission to condur $i$, eological fieldwork was provided by NACOSTI. We are grateful to Sonia Harmand. Xa、 ier Boës and the "West Turkana Archeological Project" for field facilities and discussic ns. 1 inally, we thank the two anonymous reviewers and the editor Ch. Fielding for their ar, ${ }^{\prime}$ eful comments that definitely improved the manuscript.

\section{Conflict of Interest Staıment}

Authors of the manuscript entitled: "Plio-Pleistocene sedimentation in West Turkana (Turkana Depression, Kenya, East African Rift System): paleolake fluctuations, paleolandscapes and controlling factors" claims that they have NO conflicts of interest to declare.

\section{A. Nutz (corresponding author)}

\section{REFERENCES}


Abdelfettah, Y., Tiercelin, J-J., Tarits, P., Hautot, S., Maia, M., Thuo P., 2016. Subsurface structure and stratigraphy of the northwest end of the Turkana Basin, Northern Kenya Rift, as revealed by magnetotellurics and gravity joint inversion. J. Afr. Earth Sci 119, 120-138.

Africa Oil Reports (2016). Corporate presentations. Last retrieve May 4, 2017, from http://www.africaoilcorp.com/s/presentations.asp

Aigner, T., 1985. An ancient storm depositional system: Dynamic stratigraphy of intracratonic carbonates, upper muschelkalk (middle triassic), sol th-german basin in: Storm Depositional Systems. Lecture Notes in Earth Scier ces, vol 3. Springer, Berlin, Heidelberg.

Allen, J.R.L., 1964. A review of the origin and cha ${ }^{\text {act }}$ ristics of recent alluvial sediments. Sedimentology 5, 89-191.

Allen, J.R.L., 1982. Sedimentary Struct res- -Their Character and Physical Basis, Vols. I and II. Developments in Sedimentology, 30A and 30B, Elsevier, Amsterdam, 593 p.

Arambourg, C., 1935. Esquisse śoı gique de la bordure occidentale du Lac Rodolphe. Mission scientifique de l'O,``. 1932-33. Bulletin Muséum National d'Histoire Naturelle, Paris, Vol. 1 (1), 55 p.

Arambourg, C., 1943. Co 1tribution à l'étude géologique et paléontologique du Bassin du lac Rodolphe et de Basse Vallée de l'Omo. Bulletin Muséum National d'Histoire Naturelle, Paris, Vol 1 (2), $157-230$.

Arambourg, C., Wolf, R.G., 1969. Nouvelles données paléontologiques sur l'âge des grès de Lubur (Turkana Grits) à l'Ouest du lac Rodolphe. C. R. Société géologique de France 6, 190-202.

Ashley, G.M., 2007. Orbital rhythms, monsoons and playa lake response, Olduvai Basin, equatorial East Africa ( 1.85-1.74 Ma). Geology 35, 1091-1094. 
Baumann, J., Chaumillon, E., Bertin, X., Schneider, J-L., Guillot, B., Schmutz, M., 2017. Importance of infragravity waves for the generation of washover deposits. Mar. Geol. 391, $20-35$.

Bell, J., 1978. Mathematics of Computation 32(144), 1320-1322.

Bellieni, G., Visentin, E. J., Zanettin, B., Piccirillo, E., Di Brozolo, F. R., Rita, F., 1981. Oligocene transitional tholeiitic magmatism in northern Turkana (Kenya): Comparison with the coeval Ethiopian volcanism. Bulletin Volcanologiqu e 44(3), 411-427.

Bellieni, G., Visentin, E.J., Piccirillo, E., Zanettin, B., 1987. Vo canic cycles and magmatic evolution in northern Turkana (Kenya). Tectonophysi s s-101), 161-168.

Bholowalia, P., Kumar, A., 2014. EBK-Means: A C'stering Technique based on Elbow method and K-Means in WSN. Int. J. of Com ${ }_{1}$ `te Applications 105(9), 17-24.

Billups, K., Ravelo, A.C., Zachos, J.C. Jorris, R.D., 1999. Link between oceanic heat transport, thermohaline circulation, and the Intertropical Convergence Zone in the early Pliocene Atlantic. Geology $27(1)$ (1)-322.

Blair, T.C., McPherson, J.G., 1; 24 . Alluvial fan processes and forms, in: Abrahams, A.D., Parsons, A. (Eds.), Gr on rrphology of desert environments. Chapman Hall, London, 354402.

Blair, T.C., McPherson, J.G., 2009. Processes and forms of alluvial fans, in: Parsons, A.J., Abrahams, A.D. (Eds.), Geomorphology of Desert environments. Springer, Berlin, 413467.

Bobe, R., Behrensmeyer, A.K., Chapman, R.E., 2002. Faunal change, environmental variability and late Pliocene hominin evolution. J. of Hum. Evol. 42 (4), 475-497. 
Bobe, R., Behrensmeyer, A.K., Eck, G.G., Harris, J.M., 2007. Patterns of abundance and diversity in late Cenozoic bovids from the Turkana and Hadar Basins, Kenya and Ethiopia, in: Bobe, R., Alemseged, Z., Behrensmeyer, A.K. (eds) Hominin Environments in the East African Pliocene: An Assessment of the Faunal Evidence. Vertebrate Paleobiology and Paleoanthropology Series. Springer, Dordrecht.

Boës, X., Prat, S., Arrighi, V., Feibel, C., Haileab, B., Lewis, J., Harmand, S., 2018. Lakelevel changes and hominin occupations in the arid Turkana basin during volcanic closure of the Omo River outflows to the Indian Ocean. Quat. Res y1 ? ?), 892-909.

Boisserie, J.-R., Guy, F., Delagnes, A., Hlusko, L.J., Bib , I Feyene, Y., Guillemot, C., 2008. New palaeoanthropological research in the Plin.Ple stocene Omo Group, Lower Omo Valley, SNNPR (Southern Nations, Nation iil es and People Regions), Ethiopia. C.R. Palevol 7, 429-439.

Bonnefille, R., 1983. Evidence for a coler and drier climate in the Ethiopian uplands towards 2.5 Myr ago. Nature 303, 487-49

Bonnefille, R., 2010. Cenozoic vegutation, climate changes and hominid evolution in tropical Africa. Global Planet. Chı. ng ; 72, 390-411.

Boone, S., Seiler, C., Kı'’n, B.P., Gleadow, A.J.W., Foster, D.A., Chung, L., 2017. Influence of rift superposition on lithospheric response to East African Rift System extension: Lapur Range, Turkana, Kenya. Tectonics 37, 182-207.

Boone, S., Kohn, B.P., Gleadow, A.J.W., Morley, C.K., Seiler, C., Foster, D.A., 2019. Birth of the East African Rift System: Nucleation of magmatism and strain in the Turkana Depression. Geology 47(9), 886-890. 
Boulesteix, K., Poyatos-Moré, M., Flint, S.S., Taylor, K.G., Hodgson, D.M., Hasiotis, S.T., 2019. Transport and deposition of mud in deep-water environments: Processes and stratigraphic implications. Sedimentology 66(7), 2894-2925.

Bouton, A., Vennin, E., Mulder, T., Pace, A., Bourillot, R., Thomazo, C., Brayard, A., Goslar, T., Buoncristiani, J-F., Désaubliaux, G., Visscher, P.T., 2016. Enhanced development of lacustrine microbialites on gravity flow deposits, Great Salt Lake, Utah, USA. Sediment. Geol. 341, 1-12.

Bridge, J.S., 2003. Rivers and Floodplains: Forms, Processes an . Sedimentary Record. Willey-Blackwell, Oxford, UK.

Brown F.H., Carmichael, I.S.E.1, 1971. Quaternary v' ${ }^{1}$.'noes of the Lake Rudolf region: II. The lavas of North Island, South Island and ti e B. rrier. Lithos 4, 305-323.

Brown, F.H., Harris, J., Leakey, R., Wal’ or, A., 1985. Early Homo erectus skeleton from west lake Turkana, Kenya. Nature 316, ఓQ-792.

Brown, F.H., Feibel, C.S., 1986 revision of lithostratigraphic nomenclature in the Koobi Fora region, Kenya. J Geo ${ }^{1} \mathrm{\iota}^{-}$London 143, 297-310.

Brown, F.H., Feibel, C.S , l: 88 . "Robust" hominids and Plio-Pleistocene paleogeography of the Turkana Basin, Ker ya and Ethiopia, in: Grine, F.E., (Eds.): Evolutionary History of the "Robust" Australopithecines. New York: Aldine de Gruyter, 325-341.

Brown, F.H., Feibel, C.S., 1991. Stratigraphy, depositional environments and palaeogeography of the Koobi Fora Formation, in: Harris, J.M., (Eds.), Koobi Fora Research Project Volume 3. Clarendon Press, Oxford.

Brown, D. S., 1994. Freshwater Snails of Africa and Their Medical Importance. Taylor and Francis, London. 
Brown, F.H., Haileab, B., Mcdougall, I., 2006. Sequence of tuffs between the KBS Tuff and the Chari Tuff in the Turkana Basin, Kenya and Ethiopia. J. Geol. Soc. London 163, 185204.

Bruhn, R.L., Brown, F.H., Gathogo, P.N., Haileab, B., 2011. Pliocene volcano-tectonics and palaeogeography of the Turkana Basin, Kenya and Ethiopia. J. Afr. Earth Sci 59, 295-312.

Brune, S., Corti, G., Ranalli, G. 2017. Controls of inherited lithospheric heterogeneity on rift linkage: Numerical and analog models of interaction betw $n$ the Kenyan and Ethiopian rifts across the Turkana depression. Tecton ss 36(9), 2017 TC004739. https://doi.org/10.1002/2017TC004739.

Buck, W.R., 1991. Modes of continental lithospherı er.tension. J. Geophys. Res. B: Solid Earth 96(B12), 20161-20178.

Burgess, P.M., Hovius, N., 1998. 2at ss of delta progradation during highstands: Consequences for timing of deposili $n$ in deep-marine systems. J. Geol. Soc. London 155, $217-222$.

Butzer, K.W., 1971. The Lowar Tmo Basin: geology, fauna and hominids of Plio-Pleistocene formations. Naturwiss -1l haften 58, 7-16.

Carr, C.J. 1998. River Ba sin Developments and Human Rights in Eastern Africa - A Policy Crossroads. Springer Open, 239 p.

Carroll, A.R., Bohacs, K., 1999. Stratigraphic classification of ancient lakes: Balancing tectonic and climatic controls. Geology 27, 99-102.

Carvajal, C.R., Steel, R.J., 2006. Thick turbidite successions from supply-dominated shelves during sea-level highstand. Geology 34, 665-668. 
Catuneanu, O., 2018. Model-independent sequence stratigraphy. Earth Sci. Rev. 188, 312388.

Cerling, T.E., 1979. Paleochemistry of Plio-Pleistocene Lake Turkana, Kenya. Palaeogeogr. Palaeoclimatol. Palaeoecol. 27, 247-285.

Cerling, T.E., Quade, J., 1993. Stable carbon and oxygen isotopes in soil carbonates, in: Swart, P.K., Lohmann, K.C., McKenzie, J., Savin, S. (Eds.), Climate change in continental isotopic records. Geophysical Monograph. AGU, 217-231.

Cerling, T.E., 1999. Stable carbon isotopes in palaeosol ca. hor ates in: Thiry, M., SimonCoincon, R. (Eds.), Palaeoweathering, palaeosurfaces anc . elated continental deposits. IAS Special Publications, 43-60.

Cerling, T.E., Wynn, J.G., Andanje, S.A., Birn, M.J , Kimutai Korir, D., Levin, N.E., Mace, W., Macharia, A.N., Quade, J, Pemin, C.H., 2011. Woody cover and hominin environments in the past 6 million y ars. Nature 476, 51-56.

Clifton, H.E., Hunter, R.E., Philli ${ }_{1} \quad I_{2}$., 1971. Depositional structures and processes in the non-barred high-energy neaı_hore. J. Sediment. Res. 41(3), 651-670.

Clifton, H.E., 2006. A rf exa nınation of facies models for clastic shorelines. in: Posamentier HW, Walker RG (Eds.) Facies models revisited. SEPM Special Publication 84, Tulsa, 293 337

Coe, A.L., Bosence, D.W.J., Church, K.D., Flint, S.S., Howell, J.A., Wilson, R.C.L., 2003. The Sedimentary Record of Sea-level Change. Cambridge University Press, Cambridge, UK.

Cohen, A.S., 1981. Paleoenvironments of root casts from the Koobi Fora Formation, Kenya. J. Sediment. Petrol. 52, 401-414. 
Cohen, A.S., 2003, Paleolimnology: The history and evolution of lake systems. New York, Oxford University Press, 258 p.

Cohen, A., Campisano, C., Arrowsmith, R., Asrat, A., Behrensmeyer, A.K., Deino, A.,Feibel, C., Hill, A., Johnson, R., Kingston, J., Lamb, H., Lowenstein, T., Noren, A., Olago, D., Owen, R.B., Potts, R., Reed, K., Renaut, R., Sch€abitz, F., Tiercelin, J.-J.,Trauth, M.H., Wynn, J., Ivory, S., Brady, K., O’Grady, R., Rodysill, J., Githiri, J., Russell, J., Foerster, V., Dommain, R., Rucina, S., Deocampo, D., Russell, J.,Billingssley, A., Beck, C., Dorenbeck, G., Dullo, L., Feary, D., Garello, D., Gromig, R., Johnsor, 1., Junginger, A., Karanja, M., Kimburi, E., Mbuthia, A., McCartney, T.,McNulty, E., Mu ruri, V., Nambiro, E., Negash, E.W., Njagi, D., Wilson, J.N., Rabideaux, N., Rruu, 1., Sier, M.J., Smith, P., Urban, J., Warren, M., Yadeta, M., Yost, C., Zinaye, B.. 2J16. The Hominin Sites and Paleolakes Drilling Project: inferring the environme* tal context of human evolution from eastern African rift lake deposits. Sci. Drill. 21, -16. doi.org/10.5194/sd-21-1-2016.

Dabrio, C.J., 1982. Sedimentary strı ct . -es generated on the foreshore by migrating ridge and runnel systems on microtidal ind inesotidal coasts of S. Spain. Sediment. Geol. 32, 141151.

Deino, A.L., Kingstc: J. П.. Glen, J.M., Edgar, R.K., Hill, A., 2006. Precessional forcing of lacustrine sedimentaiun in the late Cenozoic Chemeron Basin, Central Kenya Rift, and calibration of the Gauss/Matuyama boundary. Earth Planet. Sci. Lett. 247, 41-60.

de Heinzelin, J., 1983. The Omo Group, ed. Koninklijk Museum voor Midden-Afrika, Geologische Wetenschappen, Tervuren.

Delagnes, A., Roche, H. Late Pliocene hominid knapping skills: the case of Lokalalei 2C, West Turkana, Kenya. J. Hum. Evol. 48, 435-472 (2005). 
deMenocal, P.B., 2004. African climate change and faunal evolution during the PliocenePleistocene. Earth Planet. Sci. Lett. 220, 3-24.

Dott, R.J., Bourgeois, J., 1982. Hummocky stratification: Significance of its variable bedding sequences. GSA Bull. 93, 663-680.

Dunkelman, T.J., Karson, J.A., Rosendahl, B.R., 1988. Structural style of the Turkana rift, Kenya. Geology 16(3), 258-261.

Dunkelman, T.J., Rosendahl, B.R., Karson, J.A., 1989. Stru गure and stratigraphy of the Turkana rift from seismic reflection data. J Afr. Earth Sci 8,?). +89-510.

Duringer, Ph., Schuster, M., Genise, J.F., Mackaye, H.T., Vignaud, P., Brunet, M., 2007. New temite trace fossils: Galleries, nests and fungus $c_{-. .1 b s}$ from the Chad basin of Africa (Upper Miocene-Lower Pliocene). Palaeogeo `r. F alaeoclimatol. Palaeoecol. 251(3-4), 323353.

Ebinger, C.J., Yemane, T., Harding, L I., Tesfaye, S., Kelley, S., Rex, D.C., 2000. Rift deflection, migration, and pror arat:n: Linkage of the Ethiopian and Eastern rifts, Africa. GSA Bull. 112(2), 163-176.

Embry, A.F., Johannessf I1, . .r., 1992. T-R sequence stratigraphy, facies analysis and reservoir distribution in the uppermost Triassic- Lower Jurassic succession, western Sverdrup Basin, Arctic Canada. in: Vorren, T.O., Bergsager, E., Dahl-Stamnes, O.A., Holter, E., Johansen, B., Lie, E., Lund, T.B. (Eds.), Arctic Geology and Petroleum Potential. vol. 2. Norwegian Petroleum Society (NPF), pp. 121-146 (Special Publication).

Erbello, A., Kidane, T., 2018. Timing of volcanism and initiation of rifting of the OmoTurkana depression, southwest Ethiopia: Evidence from paleomagnetism. J. Afric. Earth Sci. 139, 319-329. 
Feibel, C.S., 1988. Paleoenvironments of Koobi Fora Formation, Turkana Basin, Northern Kenya. PhD thesis, university of Arizona, 327 p.

Feibel, C.S., 1993. Fresh-water stingrays from the Plio-Pleistocene of the Turkana Basin, Kenya and Ethiopia. Lethaia 26, 59-366.

Feibel, C. S. 1997. A terrestrial auxiliary stratotype point and section for the Plio-Pleistocene boundary in the Turkana Basin, East Africa. Quarter. Internat. 40, 73-79.

Feibel, C.S., 2011. A geological history of the Turkana Basin Evolutionary Anthropology: Issues, News, and reviews 20, 2016-216.

Frostick, L.E, Renaut, R.W., Reid, I, Tiercelin, J.J., 198u. Sedimentation in the African Rifts. Spec. Publ. Geol. Soc. 25.

Frostick, L.E, Reid, I., 1987. A new look at rif1s. Luulogy Today 3, 122-126.

Grant, K.M., Rohling, E.J., Westerhold, T., ?abel, M., Heslop, D., Konijnendjik, T., Lourens, L., 2017. A 3 million year index 5 , Nurth African humidity/aridity and the implication of potential pan-African Humid ; erio`s. Quarter. Sci. Rev. 171, 100-118.

Grimm, E.C., 1987. Conis · A iortran 77 program for stratigraphically constrained cluster analysis by the mei: $\mathrm{u}_{\mathrm{i}}$ incremental sum of squares. Computers and Geosciences 13, 13 35.

Haileab, B., Brown, F.H., McDougall, I., Gathogo, P.N., 2004. Gombe Group basalts and initiation of Pliocene deposition in the Turkana depression, northern Kenya and southern Ethiopia. Geol. Mag. 141, 41-53.

Hargrave, J.E., Hicks, M.K., Scholz, C.A., 2014. Lacustrine carbonates from Lake Turkana, Kenya: A depositional model of carbonates in an extensional basin. J. Sediment. Res. 84, $224-237$. 
Harms, J.C., Southard, J. B. Spearing, D.R., and Walker, R.G., 1975, Depositional environments as interpreted from primary sedimentary structures and stratification sequences. Soc. Econ. Paleontologists Mineralogists Short Course No. 2, 161 p.

Harmand, S., Lewis, J.E., Feibel, C.S., Lepre, C.J., Prat, S., Lenoble, A., Boës, X., Quinn, R.L., Brenet, M., Arroyo, A., Taylor, N., Clément, S., Daver, G., Brugal, J-P., Leakey, L., Mortlock, R.A., Wright, J.D., Lokorodi, S., Kirwa, Ch., Kent, D.V., Roche, H., 2015. 3.3Million-year-old stone tools from Lomekwi 3, West Turk?na, Kenya. Nature 521, 310315.

Harris, J.M., Brown, F.H., Leakey, M.G., 1988. Stratigra 'h ‘ ar d paleontology of Pliocene and Pleistocene localities west of Lake Turkana, Keny' C C ntributions in Science 399, 1-128.

Harris, J.M., Leakey, M.G., 2003. Geology and $v_{\varsigma_{i}} t$ brate Paleontology of the Early Pliocene Site of Kanapoi, Northern Kenya. Nr uri 1 history Museum of Los Angeles County, Los Angeles.

Haug, G.H., 1998. Effect of the for $\mathfrak{n}$ 'tion of the Isthmus of Panama on Atlantic Ocean thermohaline circulation. N $\sim$ ure 393, 673-676.

Hendrie, D., Kusznir, N, Nı.ıey, C., Ebinger, C., 1994. Cenozoic extension in northern Kenya: A quantital 'e model of rift basin development in the Turkana region. Tectonophysics 236(1), 409-438.

Hurst, A., Scott, A., Vigorito, M., 2011. Physical characteristics of sand injectites. EarthScience Reviews 106, 215-246.

Jelby, M.E., Grundvag, S-A., Helland-Hansen, W., Olaussen, S., Stemmerik, L., in press. Tempestite facies variability and storm-depositional processes across a wide ramp: Towards a polygenetic model for hummock cross-stratification. Sedimentology. 
Jervey, M.T. 1988. Quantitative geological modelling of siliciclastic rock sequences and their seismic expression, in: Wilgus, C.K. Hastings, B.S. Kendall, C.G.S.C. Posamentier, H.W. Ross, C.A., VanWagoner, J.C. (Eds.) Sea-Level Changes: An Integrated Approach, Soc. Econ. Palaeont. Miner. Spec. Publ. 42, 47-69.

Johnson, H.D., Baldwin, C.T., 1996. Shallow clastic seas, in: Reading H.G. (Eds.), Sedimentary Environments: Processes, Facies and Stratigraphy, Chapter 7. Blackwell Science, London, 232-280.

Johnson, J.G., Murphy, M.A., 1984. Time-rock model for Silı ro-l 'evonian continental shelf, western United States. Geol. Soc. Am. Bull. 95, 1349 1:50.

Joordens, J.C.A., Vonhof, H.B., Feibel, C.S., Lourens, I. ., Dupont-Nivet, G., van der Lubbe, J.H.J.L., Sier, M.J., Davies, G.R., Kroon, D., 2011. An astronomically-tuned climate framework for hominins in the Turkan $\_$B sin. Earth and Planet. Sci. Lett. 307, 1-8.

Karson, J.A., Curtis, P.C., 1994. Quaı nary volcanic centres of the Turkana Rift, Kenya. J. Afr. Earth Sci 18, 15-35.

Larrasoana, J.C., Roberts, A.F. anc Rohing, E.J., 2013. Dynamics of Green Sahara Periods and Their Role in Hominı. F rolution. PLOS one 8, e76514.

Laskar, J., Robutel, P., « ıtel, F., Gastineau, M., Correia, A.C.M., and Levrard, B., 2004. A long term numerical solution for the insolation quantities of the Earth. Astron. and Astrophys. 428, 261-285.

Leakey, R.E.F., Walker, A., 1988. New Australopithecus boisei specimens from east and west Lake Turkana, Kenya. Am. J. Phys. Anthropol. 76, 1-24.

Leakey, M.G., Feibel, C.S., McDougall, I., Walker, A., 1995. New four-million-year-old hominid species from Kanapoi and Allia Bay, Kenya. Nature 376, 565-571. 
Leakey, M.G., Spoor, F., Brown, F.H., Gathogo, P.N., Kiarie, C., Leakey, L.N., McDougall, I., 2001. New hominin genus from eastern Africa shows diverse middle Pliocene lineages. Nature 410, 433-440.

Leleu, S., Ghienne, J-F., Manatschal, G., 2005. Upper Cretaceous-Palaeocene basin margin alluvial fans documenting interaction between tectonic and environmental processes (Provence, SE France), in: Harvey, A.M., Mather, A.E., Stockes, M., (Eds.) Alluvial Fans: Geomorphology, Sedimentology, Dynamics, Geol. Soc. Lond. Spec. Publ. 251, 217-239.

Leleu, S., Ghienne, J-F., Manatschal, G., 2009. Alluvial fan d velı pment and morpho-tectonic evolution in response to contractional fault reactivat, $\urcorner n$ (Late Cretaceous-Palaeocene), Provence, France. Basin research 21, 157-187.

Lepre, C.J., Roche, H., Kent, D.V., Harmand, S. C.u nn, R.L., Brugal, J.P., Texier, P.J., Feibel, C.S., 2011. An earlier origin for the Ar net lian. Nature 477, 82-85.

Levin, N.E., Zipser, E.J., Cerling, T.E., 2009. Isotopic composition of waters from Ethiopia and Kenya: Insights into moisturc s surces for eastern Africa. J. of Geophys. Res. 114, D23306.

Levin, N.E., Brown, F.r., bunrensmeyer, A.K., Bobe, R., Cerling, T.E., 2011. Paleosol carbonates from the Tmo Group: Isotopic records of local and regional environmental change in Africa. Palaeogeogr. Palaeoclimatol. Palaeoecol. 307, 75-89.

Levin, N.E., 2015. Environment and Climate of Early Human Evolution. Annu. Rev. Earth Planet. Sci. 43, 405-429.

Lupien, R.L., Russell, J.M., Feibel, C., Beck, C., Castaneda, I., Deino, A., Cohen, A.S., 2018. A leaf wax biomarker record of early Pleistocene hydroclimate from West Turkana, Kenya. Quat. Sci. Rev. 186, 225-235. 
Macgregor, D., 2015. History of the development of the East African Rift System: A series of interpreted maps through time. J. Afr. Earth Sci 101, 232-252.

Manconi, R., Pronzato, R., 2002. Suborder Spongillina subord. nov.: freshwater Sponges. Pp. 921-1019, in: Hooper, J. N. A., and Van Soest, R.W. M., eds. Systema porifera: a guide to the classification of sponges. Kluwer Academic/Plenum Publishers, New York.

Maslin, M.A., and Trauth, M.H., 2009. Plio-Pleistocene East African pulsed climate variability and its influence on early human evolution, in Frine, F.E., Leakey, R.E., and Fleagle, J.G. (Eds.), The first humans - origins of the genu : Ho no, Springer Science, NewYork.

Maslin, M.A., Brierley, C.M., Milner, A.M., Shultz, S. Trauth, M.H., Wilson, K.E., 2014. East African climate pulses and early human :V ll tion. Quat. Sci. Rev. 101, 1-17.

Massari, F., and Parea, G.C., 1988. Pro,rac atic.sal gravel beach sequences in moderate- to high-energy, microtidal marine en rironments. Sedimentology 35, 881-913.

McDougall, I., Brown, F.H., 2008. Jrochronology of the pre-KBS Tuff sequence, Omo Group, Turkana Basin. J. Gs >l. Suc. London 165, 549-562.

McDougall, I., Brown, F … ?ự. Timing of volcanism and evolution of the northern Kenya Rift. Geol. Mag. 146(¿¹), 34-47.

McDougall, I, Brown, F.H., Vasconcelos, P.M., Cohen, B.E., Thiede, D.S., Buchanan, M.J., 2012. New single crystal 40Ar/39Ar ages improve time scale for deposition of the Omo Group, Omo-Turkana Basin, East Africa. J. Geol. Soc. London 169, 213-226.

Miall, A., 1996. The Geology of Fluvial Deposits, Springer, Berlin, Heidelberg. 
Montes, C., Cardona, A., Jaramillo, C.A., Pardo, A., Silva, J.C., Valancia, V., Ayala, C., PérezAngel, L.C., Rodriguez-Parra, L.A., Ramirez, V., Niño, H., 2015. Middle Miocene closure of the Central American Seaway. Science 348, 226-229.

Morley, C.K., Wescott, W.A., Stone, D.M., Harper, R.M., Wigger, S.T., Karanja, F.M., 1992. Tectonic evolution of the northern Kenyan Rift. J. Geol. Soc. London 149, 333-348.

Morley, C.K., Karanja, F., Wescott, W., Stone, D., Harper, R., Wigger, S., Day, R., 1999. Geology and geophysics of the Western Turkana Basins, Kenya, in: Morley, C.K. (Eds.), Geoscience of rift systems: Evolution of East Afri AAPG Stuc ies in Geology 44, 19-54.

Morley, C.K., 2020. Early syn-rift igneous dike patt‘rns, ılorthern Kenya Rift (Turkana, Kenya): Implications for local and regional sı ass $\mathrm{s}$, tectonics, and magma-structure interactions. Geosphere 16, doi.org /10.1130 $\mathrm{G}_{-\mathrm{r}}^{\prime} 02107.1$

Mulder, T., Alexander, A., 2001. The $\mathrm{p}^{1}$.ysi al character of subaqueous sedimentary density flows and their deposits. Sedimentc'ngy 48, 269-299.

Mulder, T., Syvitski, J.P.M., M:oe.., S., Faugères, J-C., Savoye, B., 2003. Marine hyperpycnal flows : initiatic? behavior and related deposits. A review. Mar. and Petrol. Geology 20, 861-882.

Murray-Hughes, R., 19د3. Notes on the geological succession, tectonics and economic geology of the western half of the Kenya colony. Report Geological Survey of Kenya 3, $8 \mathrm{p}$.

Neal, A., Richards, J. and Pye, K., 2003. Sedimentology of coarse-clastic beach-ridge deposits, Essex, southeast England. Sediment. Geol. 162, 167-198.

Neal, J., Abreu, V., 2009. Sequence stratigraphy hierarchy and the accommodation succession method. Geology 37, 779-782. 
Nicholson, 2016. The Turkana low-level jet : mean climatology and association with regional aridity. Int. J. Climatol. 36, 2598-2614.

Nicholson, S., 2017. Climate and climatic variability over eastern Africa. Rev. of Geophys. $55,590-635$.

Nutz, A., Ghienne, J-F., Schuster, M., Certain, R., Robin, N., Roquin, C., Raynal, O., Bouchette, F., Duringer, P., Cousineau, P.A., 2014. Seismic-stratigraphic record of a deglaciation sequence: from the marine Laflamme gulf th the Lake Saint-Jean (late Quaternary, Québec, Canada). Boreas 43, 309-329.

Nutz, A., Schuster, M., Ghienne, J-F., Roquin, C., Hay, M.b., Retif, F., Certain, R., Robin, N., Raynal, O., Cousineau, P.A., Team, S.I.R.O.C.C. ... Bouchette, F., 2015a. Wind-driven bottom currents and related sedimentary bc dis,s in Lake Saint- Jean (Québec, Canada). GSA Bull. 127, 1194-1208.

Nutz, A., Ghienne, J-F., Schuster, N. Dietrich, P., Roquin, C., Hay, M.B., Bouchette, F., Cousineau, P.A., 2015b. Forced if gr sssive deposits of a deglaciation sequence: example from the Late quaternary ucc:ssion in the Lake Saint-Jean basin (Québec, Canada). Sedimentology 62, 1573-161 J.

Nutz, A., Schuster, M., गU16. Stepwise drying of Lake Turkana at the end of the African humid period: a forced regression modulated by solar activity variations? Solid Earth 7, $1609-1618$.

Nutz, A., Schuster, M., Boës, X., Rubino, J-L., 2017. Orbitally-driven evolution of Lake Turkana (Turkana Depression, Kenya, EARS) between 1.95 and $1.72 \mathrm{Ma}$ : a sequence stratigraphy perspective. J. Afr. Earth Sci 125, 230-243. 
Nutz, A., Schuster, M., Ghienne, J-F., Roquin, C., Bouchette, F., 2018. Wind-driven waterbodies: A new category of lake within an alternative sedimentologically-based lake classification. J. of Paleolimnol. 59, 189-199.

Ortiz-Sepulveda, C. M., Stelbrink, B., Vekemans, X., Albrecht, C., Riedel, F., Todd, J. A., Van Bocxlaer, B., 2020. Diversification dynamics of freshwater bivalves (Unionidae: Parreysiinae: Coelaturini) indicate historic hydrographic connections throughout the East African Rift System. Molecular Phylogenetics and Evolution 148, e106816.

Owen, R. B., Renaut, R. W., 1986. Sedimentology, stratigrı phy and palaeoenvironments of the Holocene Galana Boi Formation, NE Lake Tur'‘'a'a. Kenya. J. Geol. Soc. London, Special Publications, 25(1), 311-322.

Pickford, M., Senut, B., Poupeau, G., Brown, I.P., Haileab, B., 1991. Correlation of tephra layers from the western Rift valley ( $\mathrm{J}, \mathrm{g}_{\mathfrak{a}}$ ndá, to the Turkana basin (Ethiopia/Kenya) and the gulf of Aden. C.R.A.S. 313, 223-229.

Posamentier, H., 2001. Lowstand alıu vi , 1 bypass systems: Incised vs. unincised. AAPG Bull. 85(10), 1771-1793.

Potts, R., Faith, J.T., $20154_{1} \cdots$ nating high and low climate variability: The context of natural selection and speciatı $\eta$ in Plio-Pleistocene hominin evolution. J. of Hum. Evol. 87, 5-20.

Prat, S., Brugal, J-P., Roche, H., Texier, P-J., 2003. Nouvelles découvertes de dents d'hominidés dans le membre Kaitio de la formation de Nachukui (1,65-1,9 Ma), Ouest du lac Turkana (Kenya). C. R. Palevol. 2, 685-693.

Prat, S., Brugal, J-P., Tiercelin, J.J., Barrat, J.A., Bohn, M., Delagnes, A., Harmand, S., 2005. First occurrence of early Homo in the Nachukui Formation (West Turkana, Kenya) at 2.32.4 Myr. J. of Hum. Evol. 49, 230-240. 
Ragon, T., Nutz, A., Schuster, M., Ghienne, J-F., Ruffet, G., Rubino, J-L., 2019. Evolution of the northern Turkana Depression (East African Rift System, Kenya) during the Cenozoic rifting: new insights from the Ekitale Basin (28-25.5 Ma). Geol. J. 54(6), 3468-3488.

Ravelo, C., Andreasen, D., Olivarez, A., Lyle, M., Wara, M., 2004. The Role of tropical and extratropical processes on Northern Hemisphere Glaciation. Nature 429, 263-267.

Roche, H., Delagnes, A., Brugal, J-P., Feibel, C., Kibunjia, M., Mourre, V., Texier, P-J., 1999. Early hominid stone tool production and technical sl il! 2.34 Myr ago in West Turkana, Kenya. Nature 399, 57-60.

Rooney, T.O., 2017. The Cenozoic magmatism of East-A frı.. Part I-Flood basalts and pulsed magmatism. Lithos 286-287, 264-301.

Rosendahl, B.R., 1987. Architecture of contine ${ }^{1}{ }^{d} l$ ifts with special reference to East Afri Annual Review of Earth and Planetar. Sc ences 15, 445-503.

Sage, R.F., 2004. The evolution of C4 pi. ntosynthesis. New Phytologist 161, 341-370.

Sclater, J.G., Christie, P.A.F., $1 y_{0}$ ? Continental stretching: an explanation of the midCretaceous subsidence of the ¿entralNorth Sea Basin. J. Geophys. Res., 85, 3711-3739.

Scholle, P.A., 1971. Se ime itology of fine-grained deepwater carbonate turbidites, Monte Antola Flysch (upper c etaceous), Northern Apennines, Italy. GSA Bull. 82, 629-658.

Schomaker, E.R., Vestheim Kjemperud, A., Nystuen, J.P., Sigurd Jahren, J., 2010. Recognition and significance of sharped-based mouth-bar deposits in the Eocene Green River Formation, Uinta Basin, Utah. Sedimentology 57, 1069-1087.

Schuster, M., Nutz, A., 2018. Lacustrine wave-dominated clastic shorelines: modern to ancient littoral landforms and deposits from the Lake Turkana Basin (East African Rift System, Kenya). J. of Palaeolimnol. 59, 221-243. 
Schwartz, R.K., 1982. Bedform and stratification characteristics of some modern small-scale washover sand bodies. Sedimentology 29, 835-849.

Seilacher, A., 1982. General Remarks About Event Deposits, in: Einsele G. and Seilacher A. (Eds.), Cyclic and event stratification 161-174. Springer, Berlin, Heidelberg, New York.

Schofield, N., Newton, R., Thackrey, S., Watson, D., Jolley, D., Morley, Ch., 2020. Linking surface and subsurface volcanic stratigraphy in the Turkana Depression of the East African Rift System. Journal of the Geological Society....

Schultheiß, R., Van Bocxlaer, B., Riedel, F., von Rintelen, T., Alr iecht, C., 2014. Disjunct distributions of freshwater snails testify to a central rn e $u_{\text {in }}$ ne Congo system in shaping biogeographical patterns in Africa. BMC Evolutio. arv Biology 14, e42.

Shanahan, T.M., McKay, N.P., Hughen, K.A. (ver seck, J.T., Otto-Bliesner, B., Heil, C.W., King, J., Scholz, C.A.,Peck, J., 201₹. T'e time-transgressive termination of the African Humid Period, Nat. Geosci. 8, 140- 144.

Staver, A.C., Archibald, Levin, S ‥ The global extent and determiants of savanna and forest as alternative biome sı'tes. Science 334-6053, 230-232.

Stewart, K., 2003. Fossi' Iı '⿳⺈ remains from the Pliocene Kanapoi Site, Kenya. In: Harris, J. M, and Leakey, M. G. Geology and vertebrate paleontology of the Early Pliocene site of Kanapoi, Northern Kenya. Contributions in Science 493, 21-38.

Street-Perrott, F.A., Harrison, S.P., 1985. Lake level and climate Reconstructions, in: Hecht, A.D. (Eds.), Paleoclimate Analysis and Modeling. John Wiley and Sons, New York, pp. 291-340.

Talling, P.J., Masson, D.G., Sumner, E.J., Malgesini, G., 2012. Subaqueous sediment density flows: depositional processes and deposit types. Sedimentology 59, 1937-2003. 
Tamura, T., 2012. Beach ridges and prograded beach deposits as palaeoenvironment records. Earth Sci. Rev. 114, 279-297.

Tieszen, L.L., Senyimba, M.M., Imbamba, S.K., Troughton, J.H., 1979. The distribution of $\mathrm{C} 3$ and $\mathrm{C} 4$ grasses and carbon isotope discrimination along an altitudinal and moisture gradient in Kenya. Oecologia 37, 337-350.

Tiercelin, J.-J., 1990. Rift-basin sedimentation: responses to climate, tectonism and volcanism. Examples of the East African Rift. J. Afr. Earth $₫ \sim$. 10, 283-305.

Tiercelin, J-J., Lezzar, K.E., 2002. A 300 million years history of ift lakes in Central and East Africa: An updated broad review, in: Odada, E.O., 'Mlagu, D.O. (Eds.), The East African Great Lakes: Limnology, palaeolimnology and bı div rsity. Springer, Netherlands, pp. 360.

Tiercelin, J-J., Potdevin, J.L., Morley, C.J.., Talbot, M.R., Bellon, H., Rio, A., Le Gall, B.,Vétel, W., 2004. Hydrocarbon intential of the Meso-Cenozoic Turkana Depression, northern Kenya. I. Reservoirs: de $\mathbf{o}^{\prime}$ itional environments, diagenetic characteristics, and source rock-reservoir relatin nshıs. Marine and Petroleum Geology 21, 41-62.

Tiercelin, J-J., Schuster M., Roche, H., Brugal, J-P., Thuo, P.K., Prat, S., 2010. New considerations on thr stratigraphy and environmental context of the oldest (2.34Ma) Lokalalei archaeological site complex of the Nachukui Formation, West Turkana, northern Kenya Rift. J. Afr. Earth Sci. 58, 157-184.

Tiercelin J.-J., Potdevin J.-L., Thuo P.K., Abdelfettah Y., Schuster M., Bourquin S., Bellon H., Clément J.-Ph., Guillou H., Nalpas Th., Ruffet G., 2012a. Stratigraphy, sedimentology and diagenetic evolution of the Lapur Sandstone in northern Kenya: Implications for oil exploration of the Meso-Cenozoic Turkana depression. J. Afr. Earth Sci. 72, 43-79. 
Tiercelin, J-J., Thuo, P., Potdevin, J-L., Nalpas, T., 2012b. Hydrocarbon prospectivity in Mesozoic and Early-Middle Cenozoic Rift Basins of Central and Northern Kenya, Eastern Africa, in: Gao, D. (Eds), Tectonics and sedimentation: Implications for petroleum systems. AAPG Memoir 100, 179-207.

Trauth, M.H., Maslin, M.A., Deino, A., Strecker, M.R., 2005. Late Cenozoic moisture history of East Africa. Science 309, 2051-2053.

Trauth, M.H., Maslin, M.A., Deino, A.L., Strecker, M.R., Bєrenner, A.G.N., Dühnforth, M., 2007. High- and low-latitude forcing of Plio-Pleistocene Zast African climate and human evolution. J. of Hum. Evolut. 53, 475-486.

Trauth, M.H., Larrasoana, J.C., and Mudelsee, M., 2 109. Trends, rhythms and events in PlioPleistocene African climate. Quat. Sci. Rev. 2, 299-411.

Trauth, M.H., Maslin, M.A., Deino, A.L, J ngı ‘ger, A., Lesoloyia, M., Odada, E.O., Olago, D.O., Olaka, L.A., Strecker, M.P, Tiedımann, R., 2010. Human evolution in variable environment: the amplifier lakes If E. stern Africa. Quat. Sci. Rev. 29, 2981-2988.

Van Bocxlaer, B., Van Damme D., Feibel, C.S., 2008. Gradual versus punctuated equilibrium evolution in the Turkarı brsin molluscs: evolutionary events or biological invasions? Evolution 62(3), 51:-32n.

Van Bocxlaer, B., 2011. Palaeobiology and evolution of the Late Cenozoic freshwater molluscs of the Turkana Bains: Unionidae Rafinesque, 1820, partim Coelatura (Bivalvia: Unionoidea). J. of Systematic Palaeontology 9(4), 523-550.

Van Bocxlaer, B., 2020. Paleoecological insights from fossil freshwater mollusks of the Kanapoi Formation (Omo-Turkana Basin, Kenya). J. of Hum. Evol. 140, 102341.

Van Damme, D., Pickford, M., 1999. The late Cenozoic Viviparidae (Mollusca, Gastropoda) of the Albertine Rift Valley (Uganda-Congo). Hydrobiologia 390, 171-217. 
Van Damme, D., Pickford, M., 2003. The late Cenozoic Thiaridae (Mollusca, Gastropoda, Cerithioidea) of the Albertine Rift Valley (Uganda-Congo) and their bearing on the origin and evolution of the Tanganyikan thalassoid malacofauna 498(1-3), 1.

Van Damme, D., and Pickford, M., 2010. The Late Cenozoic bivalves of the Albertine Basin (Uganda-Congo). Geo-Pal Uganda 2, 1-121.

van der Lubbe, H.J.L., Krause-Nehring, J., Junginger, A., Garcin, Y., Joordens, J.C.A., Davies, G.R., Beck, C., Feibel, C.S., Johnson, T.C., Vonhof, H.3, 2017. Gradual or abrupt? Changes in waer source of Lake Turkana (Kenya) dus ing the African Humid Period inferred from Sr isotope ratios. Quat. Sci. Rev. 174, 1-1?

Vétel, W., Le Gall, B., 2006. Dynamics of prolongec ron inental extension in magmatic rifts: The Turkana Rift case study (North Ke ıy`) Geological Society, London, Special Publications 259(1), 209-233.

Wagstaff, K., Cardie, C., Rogers, S., S.hrödi., S., 2001. Constrained K-means Clustering with Background Knowledge. Procet ${ }^{\prime} n^{\prime} s$ s of the Eighteenth International Conference on Mchine Learning (ICML 20(1); 'Villiams College, Williamstown, MA, USA.

Walker, A., Leakey, R.E. Ha.`s, J.M., Brown, F.H., 1986. 2.5-Myr Australopithecus boisei from west of Lake Tu.'kana, Kenya. Nature 322, 517-522.

Wescott, W., Morley, C., Karanja, F., 1993. Geology of the Turkana Grits in the Lariu range and Mt. Porr areas, southern Lake Turkana, northwestern Kenya. J of Afr Earth Sci 16(4), $425-435$.

Williamson, P.G., 1981. Paleontological documentation of speciation in Cenozoic Mollusks from Turkana Basin. Nature 293, 437-443.

Williamson, P.G., 1985. Evidence for an Early Plio-Pleistocene rainforest expansion in EastAfrica. Nature 315, 487-489. 
Williamson, P.G., Savage, R.J., 1986. Early rift sedimentation in the Turkana basin, northern Kenya. J. of the Geological Society London, Special Publications 25(1), 267-283.

Wright, L.D. 1977. Sediment transport and deposition at river mouth: a synthesis. Geol. Soc. Am. Bull., 88, 857- 868 .

Wright, L.D., Chappell, J., Thom, B.G., Bradshaw, M.P., Cowell, P., 1979. Morphodynamics of reflective and dissipative beach and inshore systems: Southeastern Australia. Marine Geology 32, 105-140.

Wynn, J.G., 2004. Influence of Plio-Pleistocene Aridification vn Iuman Evolution: Evidence from Paleosols of the Turkana Basin, Kenya. Americ in Jurnal of Physical Anthropology, $123,106-118$.

Yuretich, R.F., Cerling, T.E., 1983. Hydroge' ${ }^{\prime}$ ne nistry of Lake Turkana, Kenya: mass balance and mineral reactions in an ' $\mathrm{kka}^{\prime}$ 'ne lake. Geochim. Cosmochim. Acta 47, 10991109.

Zanettin, B., Visentin, E.J., Bellie : C., Piccirillo, E., Rita, F. 1983. Le volcanisme du Bassin du Nord-Turkana (Kenya): ^ ge, succession et évolution structurale. Bulletin des Centres de Recherches Explor ${ }^{+i}$ n _. ioduction Elf-Aquitaine 249-255.

Zavala, C., Arcuri, M., Dı Meglio, M., Gamero, H., Contreras, C. 2010. A genetic facies tract for the analysis of sustained hyperpycnal flow deposits, in: Slatt, M., Zavala, C. (Eds.), Sediment transfer from shelf to deep water - Revisiting the delivery system. AAPG Studies in Geology 61, 1-21.

Zhang, J., Kim, W., Olariu, C., Steel, R.J., 2019. Accommodation- versus supply-dominated systems for sediment partitioning to deep water. Geology 47(5), 419-422. 
Fig. 1. Structural and geological background of the Turkana Depression (modified from Ragon et al., 2019). (A) Location of the Turkana Depression within the East African Rift System (EARS). (B) Simplified geology and main structures in the Turkana Depression. The background topography is derived from SRTM1. (C) Large-scale transects showing graben and half-graben architectures in the (a) northern and the (b) southern Turkana Depression (Africa Oil Report, 2016).

Fig. 2. Simplified geological map of the West Turkana a:aa delineating members that composed the Nachukui Fm (modified from Harris et ai, 1:88). Distribution of faults originates from gravity map (unpublished data, Afric $(1)$ Georeferencing of sections is given in supplementary data (Table S1).

Fig. 3. Synthetic lithostratigraphic chart of $t^{\prime} \cdot r, r$ orthern Turkana Depression and major tectonic events (modified from Ragon et al.. 2019).

Fig. 4. Measured sections 1 to 18 locations in Figure 2). Lithologies and sedimentary structures allowed the interpretat on af six depositional environments (Table 1). Based on the interpretation of deposition.' 'nvironments, high- and low-frequency T-R cycles are delineated. Available abs Jlu, ages are located along sections (see Table 2 for details). Major tuff-based and onfield visı al correlations are indicated.

Fig. 5. Macroscopic facies observed in offshore (FA1) and transitional (FA2) deposits. A and B) Laminated mudstones (section 10). C) Diatomite bed intercalated in mudstones (section 16). D) Erosionally-based massive sandstone bed embedded in mudstones (section 12) interpreted as a turbidite deposited in offshore domain. E) Sandstone bed showing an erosional basal boundary overlain by planar laminations (upper flow regime) grading to wave ripple laminations (lower flow regime) recording temporal decrease of an oscillatory current (section 8). It is interpreted as a tempestite bed deposited in a transitional depositional 
environment. F) Bedding plane view of cogenetic interferent wave ripples at the top of the tempestite bed (note the polygonal pattern of ripple crests that reflect multidirectional oscillatory currents), horizontal burrows reflect post-storm bioturbation subsequent to the deposition of sand (section 8). G) Centimetric packstone beds embedded in mudstones (section 5) interpreted as distal storm deposits; they reveal a transitional depositional environment. H) Top surface of the shelly bed (section 5) showing transported gastropod shells and internal molds.

Fig. 6. Macroscopic facies observed in wave-dominated nec rsho e (FA3) deposits. A) Wellsorted sandstones showing alternations between planer ${ }^{1} \mathrm{am}$, nations and wave ripples, in places, intervals rich in heavy minerals are obs vec They reflect sedimentation in a shoreface depositional sub-environment ( $\operatorname{secti}_{\text {.1 }} 12$ ). B) Alternations between sandstone intervals and packstones attributed to shor-fac deposits (section 12). C) bedding plane view of wave ripple: note the N-S oriented crest revealing E-W oriented paleowave displacement (section 4). D) Hummocky-cross st di fieu bed (section 3). E) Close-up view of packstones made of mollusk shells (Melannides, in beach deposits (section 9). F) Packstones made of mollusk shells (Bellamya) in :eauh deposits (section 12). G) Packstones made of low-angle oblique stratifications th it rt lect successive beach faces. Low-angle stratifications suggest a relative dissipative beach (section 9). H) Moderate-angle oblique stratifications in packstones interpreted as a reflective beach (section 3). I) Bioclastic sandstones characterized by abundant bioturbations in the form of vertical burrows or root tubes. Several generations of bioturbated horizons connect to different levels that reflect successive paleosurfaces. This facies reflects a low-energy coastal swamp.

Fig. 7. Macroscopic facies observed in wave- (FA3) and river-dominated (FA4) nearshore deposits. A) Pluri-meter interval including sandstones and packstones in landward (West) dipping master bed overlain by a metric interval made of sandstones and packstones showing 
low-angle lakeward (East) dipping master beds (section 12). Together, sediments reflect retrograding washover fan deposits topped by a prograding beach (see details in Nutz et al., 2017). B and C) Fine to medium matrix-supported conglomerates. Clasts are frequently coated by carbonates. Matrix is made of gastropod shells or shell fragments and sandstones (section 16). These deposits reflect river-dominated nearshore environment. D) M-scale oncolite-rich bed (FA4) embedded in river deposits (FA5-b). E) Interval showing matrixsupported oncolites in the lowermost part grading upward to clast-supported oncolites and then to domal stromatolitic constructions interpreted as the recilt $\checkmark f$ the interruption of river influence in the nearshore domain. F and G) Channel ' $\mathrm{te}^{\prime}$ sandstone beds embedded in mudstones. They are interpreted as mouth channels and lo:es in river-dominated nearshore.

Fig. 8. Macroscopic facies observed in fluvial ( $F$...) deposits. A and B) Alternations of coarse sandstones to medium conglomerates in ${ }^{\prime} \sim \eta_{1} \cdot$ plar bodies and sandy mudstones to muddy sandstones. They reveal alternations of wic and thin channels and overbank deposits in an alluvial depositional environment. , , Riocurbated sandy mudstones and muddy sandstones. Termite nest are very well-pres ${ }^{\circ}$ vec Sediments reflect overbank deposits in alluvial plain (Table 2). D) Through cross s'raifications in coarse sandstones revealing dunes and bars in alluvial channels. E) Err sio ally-based m-scale interval made of fining-up matrix-supported conglomerate interpreted as cohesive debris flows deposit. F) Root marks in gravel bars suggesting recurrent interruptions of flows. G) Alternations of massive conglomerates revealing debris flows and coarse sandstones from dilute flows. They indicate type-1 alluvial fan deposits (sensu Blair and McPherson, 1994). H) Crudely laminated coarse sandstones to pebbles interpreted as type-2 alluvial fan (sensu Blair and McPherson, 1994).

Fig. 9. Large-scale sedimentary architectures of sequences 1 and 2. A) Thick interval of offshore lacustrine mudstones (Kataboi laga). B) Transition from offshore mudstones to alluvial deposits corresponding to the regressive part of S2. C) Close-up view on the transition 
between offshore lake and alluvial plain deposits that expresses the emersion in the upper part of S2.

Fig. 10. Large-scale sedimentary architectures of sequences 2 and 3. A) Transition from offshore to shoreface and then alluvial deposits forming the regressive part of S2. B) Close-up view on SB3 that is amalgamated with the transgressive surface. C) Incised valley affecting offshore mudstones and filled by alluvial deposits in the upper most part of S2. Above, a beach interval marks the subsequent transgression associated vith S3. D) Close-up view on the contact between offshore mudstones and alluvial san'stones to conglomerates. Desiccation cracks reveals emersion of the offshore mud t nes before alluvial sedimentation.

Fig. 11. Large-scale sedimentary architectures of senu ces 3 and 4. A) Alluvial deposits in the uppermost part of S2 overlain by beac. ar d then offshore deposits marking the transgressive part of S3. B) Offshore lud tones marking the maximum flooding interval (MFI) of S3. C) Alluvial plain deposiı corresponding to the regressive part of S3. D) Alluvial plain deposits in S4 that mark a rene ve 1 transgressive trend above the regressive part of S3 attributed to the lower part of ( 4 . ᄃ) Beaches embedded in alluvial plain deposits evidencing the proximity of a lake. $\mathrm{F}$, $\mathrm{O}$ ishore mudstones marking the maximum flooding interval

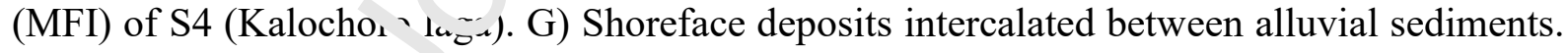
This interval shows a transgression followed by a regression of paleolake Turkana that form S4 in the proximal domain (upstream northern branch of Kokiselei laga).

Fig. 12. Large-scale sedimentary architectures of sequences 5,6 and 7. A) Coastal deposits in the uppermost part of S4 overlain by transitional deposits marking the transgression that forms the lower part of S5 (southern branch of Kokiselei laga). B) Coastal and alluvial deposits in the uppermost part of S6 overlain by offshore lake deposits marking the transgression that forms the lower part of S7 (Nachukui laga). C) Offshore mudstones 
marking the maximum flooding interval (MFI) of S7 (Nachukui laga). D) River-nearshore deposits in alluvial fan conglomerates in the upper part of S7. E) Close-up view on oncolites comprised in the river-nearshore deposits. F) Alluvial plain interval in the upper part of S7 (Nariokotome laga).

Fig. 13. Interpretrative lithostratigraphic chart of the Plio-Quaternary succession ( 4-0.75 Ma) in the West Turkana area. The chart is West-East oriented; successive lake highstands and lake lowstands are represented and a reconstruction of the pa' enlake Turkana extent through time is proposed. Periods coeval with the development o ty e-1 or type- 2 sedimentary systems are delineated. Note only the high-amplitude was 1 , vel fluctuations are presented. As this chart is synthetic, the lateral extent of he different depositional systems are approximate, potentially varying laterally from $S_{u_{n}}$ th to North.

Fig. 14. Conceptual depositional mode's $\mathrm{r}^{\mathrm{f}}$ presenting ideal type-1 and type- 2 sedimentary systems that alternatively characterize. ${ }^{1}$ sedimentation in the West Turkana area between 4 and 1.25 Ma. Transition from one systen to the other is due to variable sediment supply coming from the rift shoulder through + me $:$ nd reflects the transition from accommodation-dominated to supply-dominated systeı: a a conversely (see text for details). Modern analogues are proposed for each $\mathrm{m}_{\iota} \mathrm{de}_{\mathfrak{\imath}}$ - $\mathrm{gg} g$ sting that they represent depositional systems observed in modern extensional basins.

Fig. 15. Comparison of lake level fluctuations and sedimentary systems (details Fig. 14) evolutions with accommodation evolution, woody cover, eccentricity (Laskar et al., 2004) and previously published paleoclimate reconstructions. Note that only major tuff layers are represented.

Fig. 16. Paleolandscapes at key periods of the west Turkana evolution between $\sim 4$ and $\sim 1.25$ Ma. Types of sedimentary systems (see details Fig. 14), proportion of woody cover and 
paleoclimate in both the West Turkana and the Omo River catchment areas are indicated for each period. Main carbonate producer is specified at each period.

Table 1. Facies description and interpretation.

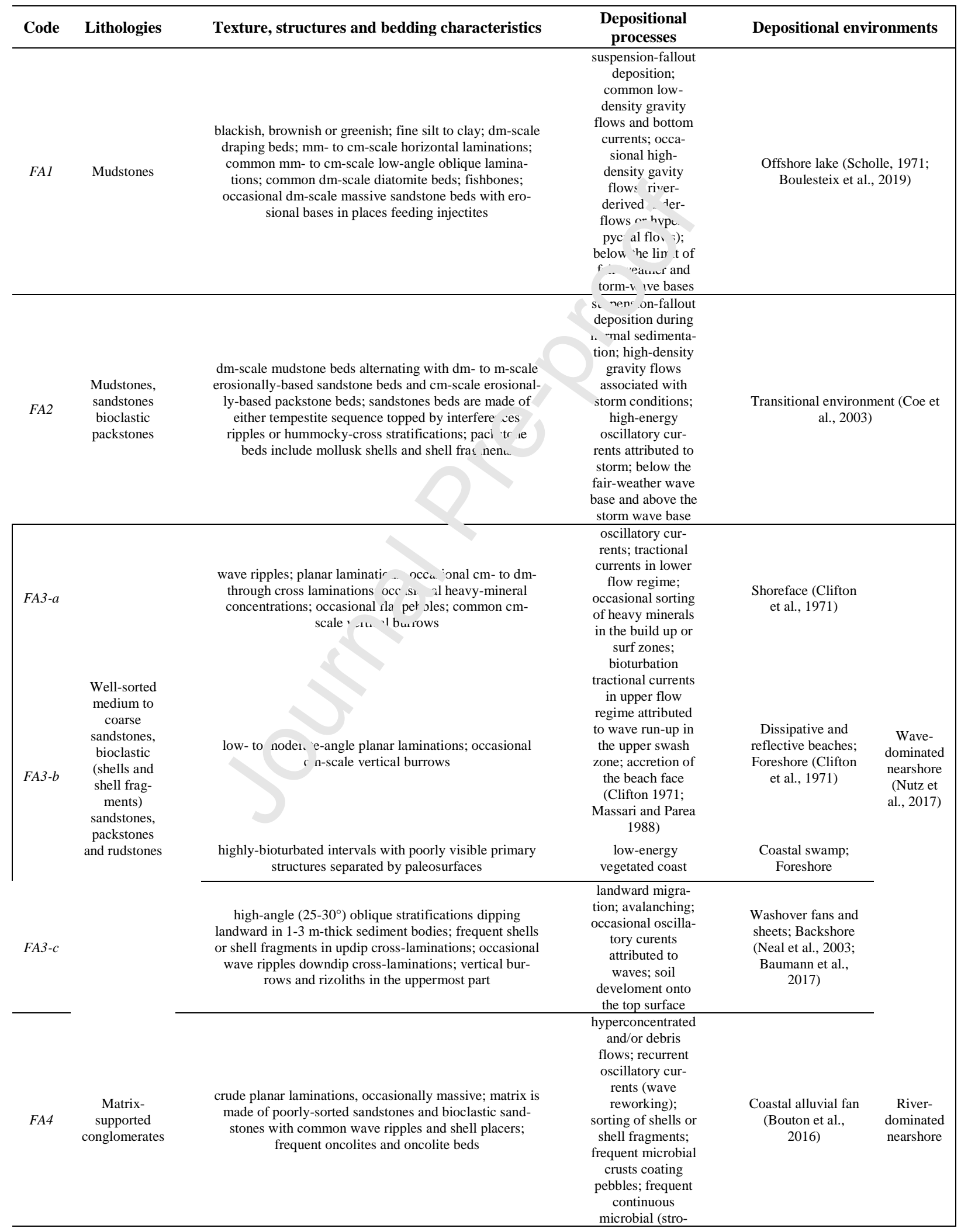




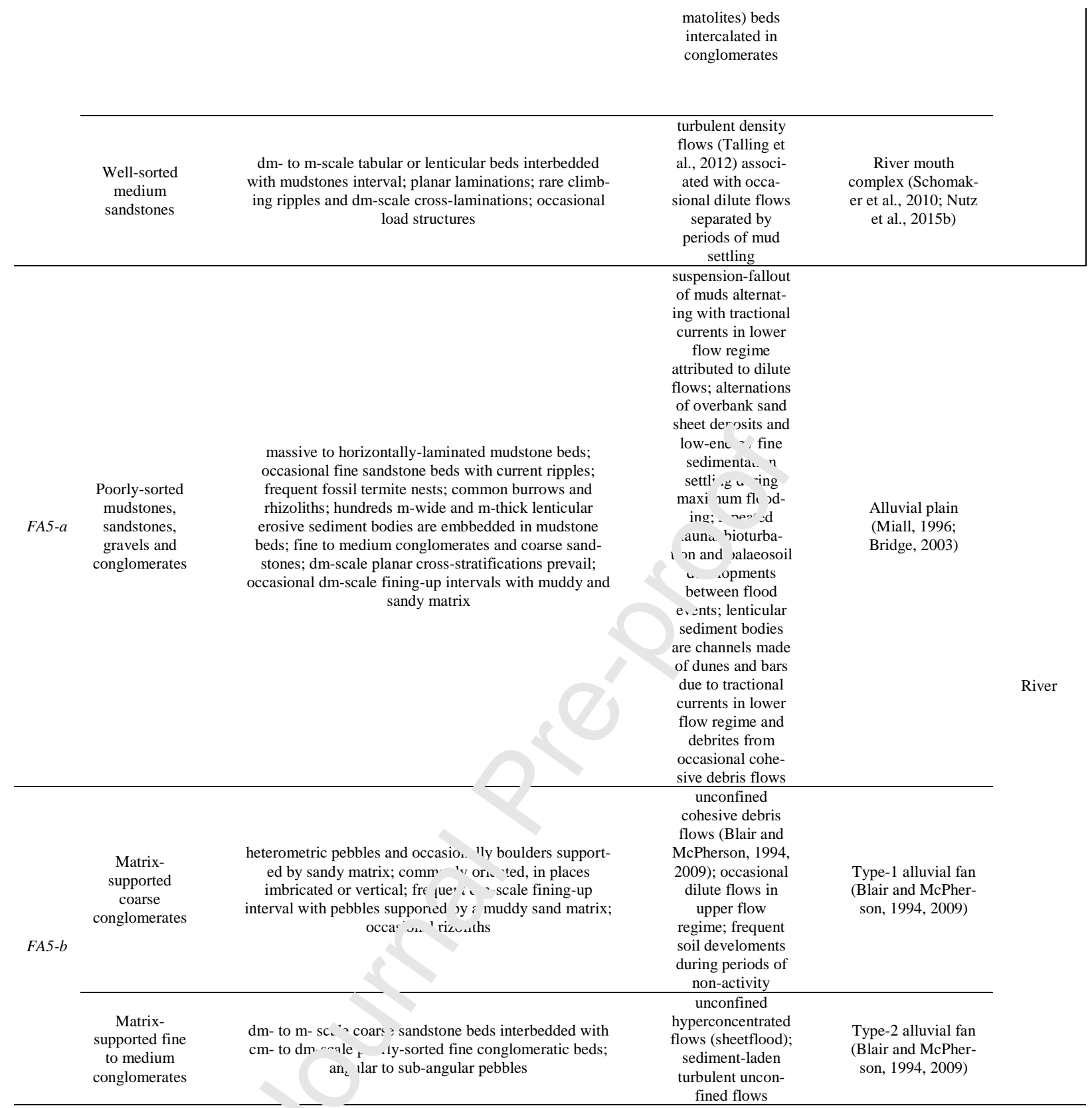

\begin{tabular}{|c|c|c|c|c|c|c|c|c|c|c|}
\hline \multirow[b]{2}{*}{$\begin{array}{l}\text { Sec- } \\
\text { tion }\end{array}$} & \multirow[b]{2}{*}{$\begin{array}{l}\text { Sam- } \\
\text { ple }\end{array}$} & \multicolumn{7}{|c|}{ Tuffs identifed by chemical analysis } & \multirow[b]{2}{*}{ Age (Ma) } & \multirow[b]{2}{*}{$\begin{array}{l}\text { Refer- } \\
\text { ences }\end{array}$} \\
\hline & & $\mathbf{n}$ & $\begin{array}{c}\mathrm{Fe}_{2} \\
\mathrm{O}_{3}\end{array}$ & $\begin{array}{c}\mathrm{Ca} \\
\mathrm{O}\end{array}$ & $\begin{array}{c}\mathrm{K}_{2} \\
\mathrm{O}\end{array}$ & Mn & $\mathrm{Ti}$ & Name & & \\
\hline 3 & $\begin{array}{c}\text { Tuff_14 } \\
.1 .2\end{array}$ & $\begin{array}{l}1 \\
4\end{array}$ & $\begin{array}{c}4.3 \\
9\end{array}$ & $\begin{array}{c}0.1 \\
7\end{array}$ & $\begin{array}{l}0 . \\
59\end{array}$ & $\begin{array}{l}14 \\
22\end{array}$ & $\begin{array}{l}19 \\
25\end{array}$ & K82-742 & $3.6 \pm 0.01$ & 2 \\
\hline 3 & Tuff_00 & 7 & $\begin{array}{c}2.9 \\
7\end{array}$ & $\begin{array}{c}0.4 \\
0\end{array}$ & $\begin{array}{l}1 . \\
01\end{array}$ & $\begin{array}{c}56 \\
9\end{array}$ & $\begin{array}{l}14 \\
77\end{array}$ & Loruth Tuff & $\begin{array}{c}3.97 \pm 0.05>T> \\
3.6 \pm 0.05\end{array}$ & 1 \\
\hline 5 & Tuff_3. & $\begin{array}{l}1 \\
4\end{array}$ & $\begin{array}{c}3.1 \\
3\end{array}$ & $\begin{array}{c}0.1 \\
9\end{array}$ & $\begin{array}{l}2 . \\
20\end{array}$ & $\begin{array}{l}10 \\
32\end{array}$ & $\begin{array}{l}14 \\
49\end{array}$ & K85-2860 & $\begin{array}{c}3.97 \pm 0.05>\mathrm{T}> \\
3.6 \pm 0.05\end{array}$ & 1 \\
\hline 6 & $\underset{2}{\text { Tuff_20 }}$ & $\begin{array}{l}1 \\
6\end{array}$ & $\begin{array}{c}1.5 \\
3\end{array}$ & $\begin{array}{c}0.3 \\
4\end{array}$ & $\begin{array}{l}2 . \\
55\end{array}$ & $\begin{array}{c}68 \\
2\end{array}$ & $\begin{array}{l}11 \\
24\end{array}$ & Tulu Bor $\beta$ & $3.44 \pm 0.02$ & 1,6 \\
\hline 7 & $\begin{array}{c}\text { Tuff_3. } \\
24\end{array}$ & 9 & $\begin{array}{c}2.6 \\
6\end{array}$ & $\begin{array}{c}0.2 \\
0\end{array}$ & $\begin{array}{l}1 \\
21\end{array}$ & $\begin{array}{c}77 \\
4\end{array}$ & $\begin{array}{c}98 \\
0\end{array}$ & Moiti Tuff & $3.97 \pm 0.03$ & 1,5 \\
\hline 7 & $\begin{array}{c}\text { Tuff_4. } \\
24\end{array}$ & $\begin{array}{l}1 \\
4\end{array}$ & $\begin{array}{c}3.1 \\
9\end{array}$ & $\begin{array}{c}0.1 \\
8\end{array}$ & $\begin{array}{l}3 . \\
21\end{array}$ & $\begin{array}{l}10 \\
69\end{array}$ & $\begin{array}{l}13 \\
81\end{array}$ & K85-2860 & $3.97 \pm 0.05>T>$ & 1 \\
\hline
\end{tabular}




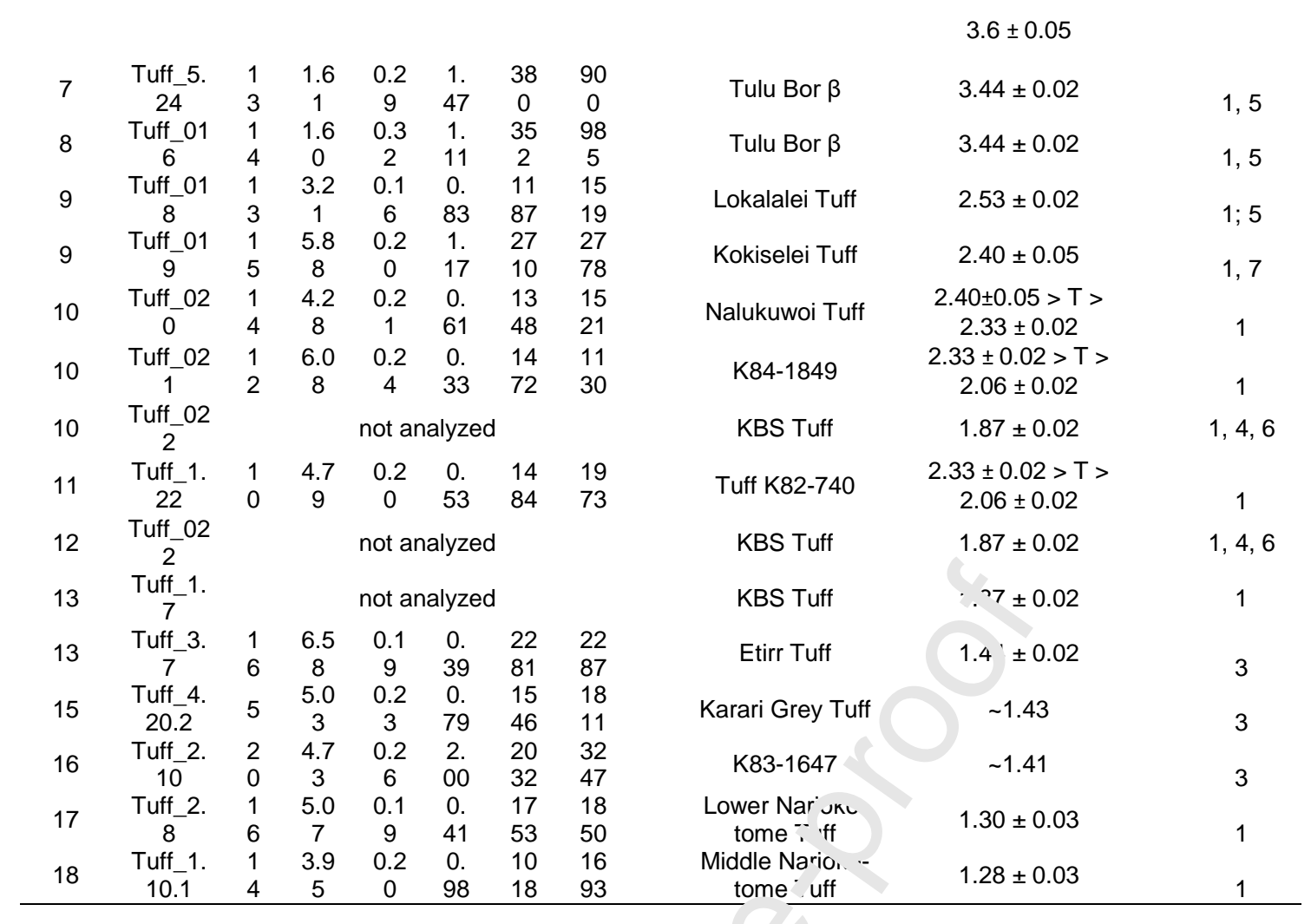

(1) Harris et al., 1988; (2) Pickford et al., 1991; (3) Brown et al. 20 : ; , t) Lepre et al., 2011; (5) McDougall et al., 2012; (6) Harmand et al., 2015; (7) Boës et al, 2018

Table 2. Geochemical analyses for tephra s. mpled in the Nachukui Fm (all values are in wt\%) and resulting identification for each $\tau_{\mu}{ }^{\circ} \mathrm{b}_{\mathrm{a}} \mathrm{sed}$ on comparison with literature. 